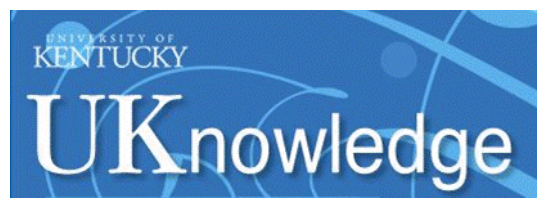

University of Kentucky

UKnowledge

Institute for the Study of Free Enterprise

Working Papers

Institute for the Study of Free Enterprise

8-2019

\title{
Can Mergers and Acquisitions Internalize Positive Externalities in Funding Innovation?
}

Leo Li

University of Kentucky, ang.li@uky.edu

Mark Liu

University of Kentucky, mark.liu@uky.edu

Follow this and additional works at: https://uknowledge.uky.edu/isfe_papers

Part of the Business Commons, and the Economics Commons

Right click to open a feedback form in a new tab to let us know how this document benefits you.

\section{Repository Citation}

Li, Leo and Liu, Mark, "Can Mergers and Acquisitions Internalize Positive Externalities in Funding Innovation?" (2019). Institute for the Study of Free Enterprise Working Papers. 13.

https://uknowledge.uky.edu/isfe_papers/13

This Research Paper is brought to you for free and open access by the Institute for the Study of Free Enterprise at UKnowledge. It has been accepted for inclusion in Institute for the Study of Free Enterprise Working Papers by an authorized administrator of UKnowledge. For more information, please contact UKnowledge@lsv.uky.edu. 


\title{
Can Mergers and Acquisitions Internalize Positive Externalities in Funding Innovation?
}

\author{
Leo Li \\ Mark Liu
}

August 2019

Institute for the Study of Free Enterprise

Working Paper 17

\author{
University of Kentucky \\ 244 Gatton College of Business and Economics \\ Lexington, KY 40506-0034
}




\title{
Can Mergers and Acquisitions Internalize Positive Externalities in Funding Innovation?
}

\author{
Leo Li and Mark Liu*
}

August 2018

\begin{abstract}
Fundamental innovation usually involves huge upfront costs, but the benefits are spread across various sectors of the economy. Given the large costs and limited appropriability of the benefits associated with the innovation, individual firms underinvest in these innovations relative to the socially optimal level. We find that mergers and acquisitions (M\&As) can internalize the positive externalities by merging firms from both the user industries and the producer industries of an innovation. Using the US patent citation dataset, we define the user and producer relationship between each pair of industries and between each pair of industry and technological class. We then show that after a merger between an innovation user and an innovation producer, the quantity of innovation output increases, and the increase is driven by targeted technological classes.
\end{abstract}

JEL classification: $\mathrm{G} 34 ; \mathrm{O} 31$

Keywords: patents, innovation, mergers and acquisitions, synergy

\footnotetext{
${ }^{*} \mathrm{Li}$ and Liu are from the Gatton College of Business and Economics, University of Kentucky, Lexington, KY 40506 (ang.li@uky.edu and mark.liu@uky.edu).
} 


\section{Introduction}

Technological innovation is a key driver of economic growth. However, innovations usually involve huge upfront costs, and the benefits associated with these innovations are spread across various sectors of society so that the value of these benefits is not easily appropriable by the innovating firm. The positive externalities of fundamental innovations cause individual firms to underinvest in innovations. For example, an electric car battery manufacturer may work on a more efficient way of storing energy. If the technology is successfully developed, it can be used not only in electric cars, but also in other industries' products, such as home appliances or cell phones. While the electric car battery manufacturer can reap the profits from selling electric car batteries, it is hard for the firm to appropriate the profits of the battery arising from its use in other industries. Therefore, the electric car battery manufacturer will underinvest in the research and development (R\&D) of the more efficient battery technology.

In this paper, we empirically test whether mergers and acquisitions (M\&As) can internalize the positive externalities by merging firms from both the user industries and the producer industries of an innovation. After the merger or acquisition, the combined firm is able to capture the benefits associated with the innovation in both user industries and producer industries. Therefore, the combined firm should have greater incentives to fund the innovation and file more patents.

The notion that innovative activities are difficult to finance in a freely competitive marketplace has been around for a long time ${ }^{1}$, and this is a typical positive externality problem in economics. Economists have realized that the market can sometimes (at least partly) internalize

\footnotetext{
${ }^{1}$ The discussion perhaps starts with the classic articles of Nelson (1959) and Arrow (1962). Even in the presence of various mechanisms to increase appropriability such as patents and other forms of intellectual property protection, the underinvestment may not completely go away. For example, Mazzucato (2015) points out that fundamental innovations underlying such popular products as the iPod and iPhone manufactured by Apple, and Google's search algorithm, were funded by U.S. government in various ways (e.g., through agencies such as DARPA or the National Science Foundation).
} 
the positive externality. For example, beekeepers can collect honey from their hives, but the bees will also pollinate surrounding fields and thus aid farmers. If the beehives and fields are owned separately, the number of beehives may be lower than the socially optimal level. However, if the farmer also owns beehives, he or she will increase the number of beehives. Similarly, by funding firms from both the user industries and the producer industries of an innovation, the combined firm has incentives to increase the innovation because it will capture a higher proportion of the benefits of the innovation than it would otherwise.

Empirically, we test this hypothesis by using two datasets: M\&As from the Thomson Reuters Securities Data Company (SDC) Platinum, which contains data on how firms merge with each other, and a novel US patent and citation dataset, which contains data on firms that file the patents and citations received by the patents. We start by defining the upstream (innovationproducing) and downstream (innovation-using) firms for each industry using the patent citation dataset. If patents filed by firms from one industry are most cited by another industry in the previous 10 years, we define the former industry as the upstream industry and latter industry as the downstream industry. Firms in the upstream industry are the innovation producers, while firms in the downstream industry are the innovation users. We then show that after a merger between firms in upstream and downstream industries (i.e., both producers and users of an innovation), the combined firm becomes more innovative compared to the case where the two firms remain separate. We use various measures of innovation that are used in the literature.

Bena and Li (2014) ask a similar question and find that if two firms share the same innovation knowledge base, the combined firm after the merger is more productive compared to the case where the two firms remain separate. One drawback of their result comes from the firm level data. For instance, Google Inc. announced an acquisition against Motorola Mobility in 2011. 
In the year before the announcement, Google filed around 1,000 patents in multiply technological classes, and Motorola Mobility had 6,800 pending patents, yet not all these technological classes of the acquirer share the same knowledge with the innovation of the target. The synergy of innovation related mergers and the increase of innovation output should mainly come from the targeted technological classes.

To better pin down the effect of mergers on patents, we further construct a firm tech-class level dataset. Instead of providing associated SIC codes in patent documents, the United States Patent and Trademark Office (USPTO) assigns patents to three-digit technological classes that are based on technology categorization instead of final product categorization. Because targets in about $90 \%$ of the M\&A deals are private firms, their patent and technological class data are unavailable. Therefore, in this setting, we know the technological classes of the acquirers and the industries the targets belong to. Similar to the industry-to-industry relationship, we define an industry-to-technological-class relationship using the patent citation dataset. If patents filed by firms from one industry are most cited by (most likely to cite) patents from one technological class in the previous 10 years, we define that the industry and the class have a producer-user (userproducer) relationship. We can then compare the affected technological classes to other unaffected classes to better pin down the effect of mergers between innovation producers and users. Moreover, a technological class can be related to the target firm in one merger and unrelated in another merger at the same time, so we can then capture the effect of related M\&A within the same technological class. We show that targeted firm tech-classes become more innovative after mergers compared to other firm tech-classes.

If M\&As between innovation users and producers do internalize positive externalities and incentivize innovation, firms should fund more innovation in targeted technological classes and 
less in other classes, compared to before mergers. We find that this is indeed the case: we observe an increase of innovation output in the targeted classes and a decline in other classes. Moreover, we find that financially unconstrained firms tend to reallocate resources to targeted classes from other unaffected classes.

Finally, we test the impact of innovation related M\&As on tech-class level innovation. If a technological class is more likely to be involved in related mergers, the innovation should be enhanced in that technological class. Our results support this hypothesis.

The first identification challenge comes from the concern that the increase may be mechanical. It may be the case that innovation increases after mergers not because of the synergy or internalizing positive externality, but simply due to the fact that target firm files patents anyway. For example, Sevilier and Tian (2012) show that firms undertake M\&As for the purpose of acquiring innovation. To address this concern, first, we use unrelated mergers as the control group in the firm-level regressions so that the mechanical increase cancels out with each other. This may not eliminate the concern of mechanical increase because one can argue that target firms in related mergers tend to be more innovative. We address this concern in the firm-class level regressions. Targets and acquirers in related mergers do not necessarily file patents in the same technological class. In fact, among the M\&A deals with public target firms, the technological classes of acquirers and targets do not overlap in most of the deals. Moreover, even when acquirers and targets have overlapping technological classes, they are not necessarily defined as targeted classes, and are included in the control group. Therefore, the increase of patents in targeted technological classes are not caused by mechanical reasons.

The second concern is that the increase of innovation and M\&A activity can be endogenous. For example, a firm with large amount of free cash may invest more in innovation and M\&A 
activities at the same time. We address this concern by including M\&A deal fixed effects and technological class fixed effects in the regressions. To further establish a causal effect between M\&A activity and innovation, we follow the method developed by Savor and Lu (2009) and compare the change of innovation around successful mergers to that of mergers withdrawn for reasons that are exogenous to innovation. For example, we exclude mergers that are withdrawn due to the disagreement on the future development strategy between the acquirer and the target because this reason may be related to future innovation strategy. By ruling out the systematic relation between a firm's innovation and the probability of a failed merger, this strategy can help identify the causal effect of a firm's M\&A on its innovation output. A firm that decides to invest more in innovation can choose to acquire another firm with relevant knowledge to achieve this goal. However, in the case where the merger is withdrawn, the innovation output in that firm does not increase. Our result is consistent with existing literature and shows that the innovation output increases more after successful user-producer mergers compared to failed user-producer mergers.

Another identification challenge comes from shocks at the industry level. For instance, suppose an industry is growing fast and its product market is becoming more and more competitive. Firms will merge to exploit synergies to differentiate its products from its competitors. By the same token, the innovation of the industry may also reach the peak given the inverted-U shape relationship between competition and innovation (Aghion, et al 2005). This industry with more patents are more likely to become the top producer or user of innovation of other industries. Therefore, industry level shocks may be driving both innovation related M\&As and innovation outputs. Fortunately, the concern of such shocks can be mitigated by using firm tech-class level data because the tech-class level relationship is less correlated with acquirers' industry condition. In addition, we control for any shocks to technological classes by including a full set of class-year 
fixed effects. The fixed effects are identified because a technological class can be involved in a related merger and an unrelated merger at the same time.

Our paper contributes to the M\&A literature and the innovation literature in at least two ways. We are the first to develop a measure of innovation-user and innovation-producer industries and a user-producer relationship between industries and technological classes, which can be used in future research. And we show that M\&As between an innovation-user and an innovationproducer can internalize the positive externalities associated with funding innovation, and the increase of innovation is driven by the targeted technological classes.

The remainder of the paper is organized as follows. We discuss the related literature in section 2. Sample construction, empirical methodology, and sample overview are described in section 3. Empirical results on changes in innovations around M\&As are reported in section 4. Section 5 concludes the paper.

\section{Literature Review}

Our study is related both to studies in firm innovation and studies in M\&As. It is well documented that innovation is an important driver of firm performance (Bloom and Van Reenen 2002; Levine 2005), and innovation's importance is well understood by the market, as the number of citations received by patents correlates with a firm's market value (Hall, Jaffe, and Trajtenberg 2005). Kogan et al. (2017) also find that the stock market positively reacts to the approval of patents that are eventually highly cited, and that such patents predict firm productivity. Given the importance of firm innovation, it is essential to understand the factors that incentivize it. Some papers empirically show that CEOs' incentives have a significant impact on motivating innovation. For 
example, both corporate venture capital (Chemmanur, Loutskina, and Tian 2014) and stock options in CEOs' compensation (Chang et al. 2015) motivate managers to undertake innovative projects.

Despite the importance and incentive of innovation, funding it can be difficult. Brown, Fazzari, and Petersen (2009) is the first paper to show that cash flow and external equity are essential to financing innovations in young firms. Large, publicly traded firms also depend on banks (Hall and Lerner 2010), and they receive cheaper bank loans if they produce higher-quality patents. That being said, firms and lenders consider the cost of innovations and the value of the benefits associated with the innovations. If the benefit of innovation is not easily appropriable and spread across industries, this positive externality will cause firm to underinvest in innovation.

Several papers study the effect of M\&As on innovation. Seru (2014) shows that innovation decreases after diversifying M\&As because inventors become less productive. Sevilir and Tian (2012) find a positive relationship between M\&As and innovation and show that acquiring innovation is an important motive for undertaking M\&As. Our paper differs in that we consider the citation relationship of the acquirer and the target firm prior to the M\&A and study the synergy from the internalization. Phillips and Zhdanov (2012) find that acquiring firms that have successfully innovated can be a more efficient path to obtaining innovation than innovating directly oneself. We take care of the mechanical increase of innovation after M\&As by using unrelated M\&As as a control group and using firm-class level data. The paper that is most relevant to ours is Bena and $\mathrm{Li}$ (2014). They show that M\&As are more likely to be conducted between firms with technological overlap, and the innovation output increases after such mergers. Their identification strategy is to compare successful mergers to withdrawn mergers. Our paper is different in the sense that our main results come from all available mergers that include about 2,804 deals, compared to the 60 withdrawn mergers in their analysis. Additionally, we use firm- 
technological-class level data to better pin down the effect of related mergers on innovation. We will elaborate on this idea in the empirical part of the paper.

This paper differs from the previous literature in that it is the first to study the citation links between industries and technological classes using a novel patent citation dataset. The paper shows that merging two firms from the user industry and the producer industry mitigates the positive externalities of innovations and enhances the innovation output afterward. We are also the first to study the effect of M\&As on firm tech-class level innovation, which allows us to better pin down the effect and mitigate the endogeneity concern.

\section{Data}

\subsection{Sample Selection}

We use a novel dataset of patents and citations constructed by Kogan et al. (2017). The dataset includes the entire history of US patent documents from Google Patents. The United States Patent and Trademark Office (USPTO) allows only individuals to be the inventor, but an individual can assign granted patent to another person or to a corporation. Therefore, patents always have an inventor, and sometimes they have been assigned to one or more corporations. Kogan et al. then matched the corporation names to firms in the Center for Research in Security Prices (CRSP) stock return database. The dataset covers patents granted from 1926 to 2010 that are assigned to firms in the CRSP database. The USPTO also keeps track of all citations for patents granted from 1976 to 2001. Compared to the NBER patent project, this dataset provides 1.9 million patents that can be matched to companies, 27 percent of which are not included in the NBER data. ${ }^{2}$ Another commonly used measure of innovation is R\&D expenditures, but 65 percent of firm-year

\footnotetext{
${ }^{2}$ The dataset is provided by Noah Stoffman on his website (https://iu.app.box.com/v/patents). More details of the patent data construction can be found in the paper and the online appendix of Kogan et al. (2017).
} 
observations from Compustat have missing values. Missing R\&D expenditures in financial statements do not necessarily mean that the firm is not innovative (Koh and Reeb 2015). Therefore, compared to $R \& D$ expenditures, patent-based metrics better reflect the productivity of $R \& D$ and more realistically reflect a firm's innovation performance. Using this patents and citations dataset allows us to measure the innovation output for every public firm in every year.

In addition, the USPTO has developed an elaborate classification system for the patented inventions. This system categories technologies into about 4003 -digit patent classes, and each patent is assigned to a technological class. Using the classification data, we can further measure the innovation output of each firm in each class and analyze the effect of M\&A on the firm techclass level.

To identify a sample of M\&As, we begin with all completed US M\&As with effective dates from 1984 to 2007, covered by the mergers and acquisitions database of Thomson Reuters' SDC Database ${ }^{3}$. We exclude the deal if: (1) either the acquirer or the target firm is from the financial industry (Standard Industrial Classification [SIC] codes 6000 to 6999); (2) the transaction value of the deal is less than $\$ 10$ million, to drop the small and economically insignificant deals; (3) the acquiring firm cannot be matched to Compustat/CRSP; (4) the acquiring firm did not file any patent the year before the merger; (5) the acquiring firm exists fewer than three years before or after the M\&A, because there is a few years' lag between patent filings and investments on innovation. To make sure the acquirers are innovative before mergers, we require them to have at least one patent the year prior to the mergers. We do not require the target firms to be matched to Compustat/CRSP because most of the target firms are private firms; excluding them would result

\footnotetext{
${ }^{3}$ Our sample begins in 1984 because information on M\&As in SDC is less reliable before 1984. Our sample period ends on December 31,2007, three years before our patent data end in 2010. Allowing a three-year period after the last merger can mitigate the potential truncation bias in our innovation output measures.
} 
in a large drop in the sample size. Large firms tend to buy innovation by acquiring small private firms that are engaged in $R \& D$, so excluding the sample of private target firms would lead to biased estimation. Our final M\&A sample contains 2,804 deals for the period 1984 to 2007.

\subsection{Related M\&As and targeted tech-classes}

To examine how mergers between innovation-user and innovation-producer can enhance innovation output, we need to define the user-producer relationship between industries. In year $t$, industry $i$ and $j$ are innovation related industries if in the previous 10 years $^{4}$, the patents filed by firms in industry $\mathrm{i}$ is among the top-3 industries that cite (are cited by) patents filed by firms in industry j. Similarly, we define the relationship between industries and technological classes. In year $t$, industry $i$ and technological class $j$ are related if in the previous 10 years, the patents filed by firms in technological class $\mathrm{j}$ is among the top-3 classes that cite (are cited by) patents filed in industry i. In this definition, the user-producer relationship updates every year and can capture the changing relation over time. In our final sample, 1,567 deals are between firms from related industries (related M\&As), and 12\% of the technological classes of acquirers (targeted classes) are related to the target firms' industry.

\subsection{Variables}

We employ various measures of innovation to capture different aspects of a firm's innovation performance. We begin with the number of patents filed in each year and the number of citations received by patents in the subsequent three years after the patents are granted. We count patents at the time when they are filed with the USPTO because inventors have the incentives to file the patent as soon as it is finished, the file date is the closest to the actual time of innovation. The citations are counted after the publication date of a patent because this is when a patent is revealed

\footnotetext{
${ }^{4}$ Using previous 3 years does not change our results.
} 
to the public and starts to be cited. Because the distribution is positively skewed, we use the natural logarithm of these innovation measures.

Because there is heterogeneity across technological classes, some classes have more patents and receive more citations than other classes, we use citation-weighted number of patents and patent index to adjust for this heterogeneity. The citation-weighted number of patents scales the patent citation by the average number of citations a patent received in the same year and in the same technology class (Hall, Jaffe, and Trajtenberg 2001). We also follow Bena and Li (2014) to calculate the patent index of each firm. The patent index is the patent number adjusted by the median value of each technology class. ${ }^{5}$ However, the measures of patents and citations are meaningful only when used comparatively, the fact that a firm files 10 or 100 patents does not tell you whether the firm is highly innovative. That is, the evaluation of the patent intensity need to be made with references to some "benchmark" intensity. Therefore, we control for firm fixed effects or class fixed effects in the regressions.

In the analyses, we use the measures of innovation output as the dependent variables. Our key test variables are the After dummy, which equals one if the observation is after M\&As and zero otherwise, and the Related dummy, which equals one if the deal is a related M\&A and zero otherwise. The After dummy captures the change of innovation around M\&As, and the Related dummy captures the difference between related M\&As and unrelated M\&As. In the multivariate tests, we include control variables that may affect firm innovation. $R \& D /$ Assets is the $\mathrm{R} \& \mathrm{D}$ expense adjusted by total assets. Sales is the total sales as a measure of firm size. $R O A$ is the return on assets, defined as the operating income before depreciation, divided by total assets. Leverage is the total debt divided by total assets. Capital expenditure, Capex, is the capital expenditure

\footnotetext{
${ }^{5}$ Details of how to construct these measures are reported in the Appendix.
} 
divided by total assets. Tangibility is the total gross property, plant, and equipment divided by total assets. TobinQ is the ratio of market value to book value of assets. $H H I$ captures the competition of a 3-digit SIC industry.

Table 1 reports the summary statistics of firm innovations and control variables. Panel A shows the summary of all acquiring firms during the sample period. Panels B, C, and D report the M\&A characteristics. From 1984 to 2007, 2,804 deals of M\&As are executed, of which 1,583 deals are related M\&As. Panel E shows the summary statistics of firm-class level innovation. An average firm file patents in 3.8 technological classes in the year before mergers, the median number is 3. An average firm file patents in 12.3 technological classes during the entire sample period, the median number is 10 .

[Insert Table 1 about here]

\section{Empirical Results}

\subsection{Univariate tests}

Because firm innovation and the decision to merge are endogenously determined, it is difficult to compare innovation between firms involved in related M\&As and unrelated M\&As. Therefore, we use a panel structure approach to control for many factors that affect both innovation and M\&A decisions, such as R\&D, ROA, and leverage. Before doing so, we provide some simple summary evidence on differences in firm innovation between related and unrelated M\&As.

We first conduct a before-after comparison among firms involved in related M\&As and unrelated M\&As, respectively. In Table 2, Panel A reports the change of firm innovation and characteristics around related M\&As. The variables are the average value of three years' observations before or after M\&As. The number of patents, citation-weighted number of patents, 
and patent index all increase significantly after related M\&As. The originality of patents also increases. In Panel B, we conduct the before-after test among firms involved in unrelated M\&As, and the change of generality and patent index are insignificant. Panel $\mathrm{C}$ reports comparisons of the change after related M\&As and unrelated M\&As. The results show that the number of patents, the citation-weighted patents, the patent index, originality, and generality all increase by a higher amount after related M\&As compared to unrelated M\&As.

\section{[Insert Table 2 about here]}

\subsection{Multivariate tests of firm-level innovation}

We use a panel structure to analyze the innovation around related M\&As. Because the increase of innovation output can be mechanical, we use unrelated M\&As as the control group and perform the difference-in-difference tests in a multivariate setting. Specifically, we estimate the following regression using a sample of all related and unrelated M\&As:

$$
\begin{aligned}
\text { Innovation }_{i, t}= & \beta_{0}+\beta_{1} \times \text { After }_{i, t}+\beta_{2} \times \text { After }_{i, t} \times \text { Related }_{i, t} \\
& +\beta_{3} \times \text { Controls }_{i, t}+\psi_{i}+\delta_{t}+\varepsilon_{i, t},
\end{aligned}
$$

where Innovation $_{i, t}$ is one of the innovation measures of firm $i$ in year $t$; After $i, t$ is a dummy that equals one if it is after the M\&As and zero otherwise; Related $d_{i, t}$ equals one for mergers between innovation users and innovation producers (related M\&As) and equals zero otherwise. We keep 6 years data before and after each M\&A because it usually takes a few years for the acquired knowledge to turn into patents. We include M\&A deal fixed effects to difference away any timeinvariant differences among deals ${ }^{6}$ and year fixed effects to control for common trends in all M\&A deals. Therefore, this model estimates the change over time in innovation output for the same cross-section units. The variable of interest is the interaction term of After dummy and Related

\footnotetext{
${ }^{6}$ The coefficient on Related $_{i, t}$ is absorbed by deal fixed effects.
} 
dummy that captures the change of innovation after the acquiring firm merges with a target firm that is in the upstream or downstream industries of patent citations. The hypothesis that related M\&As can internalize the positive externalities predicts that the coefficient $\beta_{2}$ will be positive, meaning that the combined firm will benefit from the internalization and be more productive after related mergers compared to unrelated mergers.

We include control variables commonly used in the previous literature. Bena and $\mathrm{Li}$ (2014) find that firms that are larger, have higher ROA, and have higher market-to-book ratios are more likely to be the acquirers. We therefore include the variable TobinQ to control for investment opportunities, defined as the ratio of the market value of assets to the book value of assets; Sales to control for size; and $R O A$ to control for profitability, defined as operating income before depreciation divided by total assets. Other factors include leverage, capital expenditures, tangibility, and R\&D expenses. Results are reported in Table 3. In all regressions throughout the paper, we control for M\&A deal fixed effects and year fixed effects, and the $p$-values reported are based on firm-level clustered standard errors.

\section{[Insert Table 3 about here]}

In the first column of Table 3, the dependent variable is the total number of patents filed by a firm, and the coefficient on the interaction term is positive and significant at the 1 percent level. The result indicates that the increase of innovation after related M\&As is greater than that after unrelated M\&As. In columns 3 to 6 , we use different measures of firm innovation and the coefficients are all significantly positive. In column 2 , the coefficients on the interaction term are insignificant but still show a positive sign. In summary, the difference-in-difference tests in Table 3 show that related M\&As enhance the quantity and quality of innovation output more than unrelated M\&As do. The results indicate that after the merger of two firms from related industries, 
the combined firm is more likely to benefit from the innovation, and thus innovation output is enhanced to a new, optimal level.

The coefficient on After $\left(\beta_{1}\right)$ captures the effect of unrelated M\&As on innovation output, and they are all significantly negative as shown in Table 3. This finding is consistent with Seru (2014) which shows that innovation ability decreases after conglomerating mergers. Although our definition of unrelated is different from conglomerating, most unrelated mergers are indeed between firms from different industries. In addition, our results show that the decrease of innovation output is mitigated if the mergers are between an innovation user and an innovation producer.

\subsection{Firm tech-class level test}

The synergy between innovation user and innovation producer makes it easier for firms to appropriate the value of innovation, obtain relevant knowledge, internalize costs, more likely to fund innovation and thus enhance innovation output after mergers. However, this synergy and enhancement should mainly occur in the targeted technological classes rather than every area of research within the firm. To examine the effect of M\&As on the targeted technological class and other classes within the same firm, we estimate the following firm tech-class level difference-indifference specification:

$$
\begin{aligned}
\text { Innovation }_{i, j, t} & =\beta_{0}+\beta_{1} \times \text { After }_{i, t}+\beta_{2} \times \text { Targeted }_{\text {Class }}, j, t, t \\
& +\beta_{3} \times \text { After }_{i, t} \times \text { Targeted Class }_{i, j, t} \\
& +\beta_{4} \times \text { Controls }_{i, t}+\psi_{i}+\delta_{j, t}+\varepsilon_{i, j, t}
\end{aligned}
$$

where $\mathrm{i}$ indexes firms, $\mathrm{j}$ indexes technological classes, $\mathrm{t}$ indexes years. After $i, t$ is a dummy that equals one if it is after the M\&As; Targeted Class $_{i, j, t}$ equals one if the technological class $\mathrm{j}$ of the acquirer $i$ is in a user-producer relationship with the target's industry. The coefficient of interest is $\beta_{3}$, which measures the effect of M\&As on targeted classes compared to other classes. We include 
firm fixed effects and class by year fixed effects in the regressions. The class by year fixed effects control for any technological class level shocks.

The dependent variables are various measures of firm tech-class level innovation output, include the number of patents filed by firm $i$ in year $t$ that belong to technological class $j$; the number of citations received by these patents in the subsequent 3 years after granted; the citationadjusted number of patents; and the patent index. The control variables are the same as those in equation (1). To mitigate the effect of outliers, we winsorize all variables at the $1^{\text {st }}$ and $99^{\text {th }}$ percentiles. To account for serial and cross-sectional dependence across classes within the same firm, we cluster standard errors at the firm level.

Table 4, Panel A shows the effect of M\&As on innovation output of the targeted technological classes and other classes within the same firm. As shown in column 1, after mergers, the number of patents in the targeted classes increases $4.7 \%$ more compared to innovation in the other classes. The coefficients on the interaction term are positive in Column 3 and 4, and they are both significant, meaning that the citation-adjusted patents and the patent index both increase significantly in targeted classes compared to those of other classes.

[Insert Table 4 about here]

The interaction terms in the above difference-in-difference model show the difference between targeted classes and other classes, but do not report the exact changes in these two categories. It could be the case that the innovation in targeted classes increase while innovation in other classes remain the same, or the firm reallocate resource from other classes to the targeted classes. In four out of the six columns in Table 4, the coefficients on After $\left(\beta_{1}\right)$ are significantly negative, meaning that the innovation output decreases in other technological classes. The sum of coefficients on After $\left(\beta_{1}\right)$ and the interaction term $\left(\beta_{3}\right)$ captures the effect of M\&As on targeted 
technological classes, and they are all positive, meaning that the innovation output increases in targeted technological classes. These firm tech-class level results support the hypothesis that firms reallocate resources across technological classes within firms.

\subsection{Reallocation of innovation within firms}

Reallocation of resource within firms rest on the premise that firms are financially constrained, so that it is necessary to winner-pick the best performing sectors (Stein 1997). Giroud and Mueller (2015) find that financially constrained firms reallocate capital and labor to plants experiencing positive shocks, but there is no need for unconstrained firms to reallocate within firms because they can use external funding. Similarly, we expect to see reallocation of innovation funding in financially constrained firms. To test this hypothesis, we examine the effect separately for financially constrained and unconstrained firms by estimating equation (2) in two subsamples. We use the KZ index (Kaplan and Zingales 1997) to measure financial constraints. A firm is financially unconstrained (constrained) if the firm's KZ index is below (above) the median of all firms in the year before M\&As. Results of constrained firms are reported in Table 5, Panel A. Panel B reports results using unconstrained firms.

[Insert Table 5 about here]

In all six columns of Panel A, the coefficient on the After dummy are significantly negative, meaning that the quality and quantity of innovation output decrease in unaffected tech-classes. The sum of coefficients on the After dummy and After * Targeted Class estimate the effect of M\&A on targeted tech-classes, and the values are close to zero in column 1,3 , and 4 , meaning that the quantity of innovation output does not change in targeted classes after M\&A in financially constrained firms. However, in column 5 and 6, the originality and generality increase significantly in targeted classes. The results indicate that although financially constrained firms have trouble in 
funding innovation after related M\&As, the mergers between innovation users and innovation producers can enhance the quality of innovation output. In Panel B, the coefficients on After and After * Targeted Class show that M\&A enhance the innovation output in targeted classes in financially unconstrained firms, while it remains the same in other unaffected classes. The difference of results in Panel A and B indicates that financially constrained firms have to reallocate resource from other classes to fund targeted classes, while unconstrained firms can fund more innovation in targeted classes and maintain the innovation level in other classes.

Another premise of reallocation is that firms conduct innovative research in multiple technological classes. A firm operating in many classes may be easier to move resource to one important class. Therefore, we estimate the effect of mergers on innovation with respect to the number of technological classes. A dummy Few Classes equals one if in the year prior to mergers, the number of technological classes of a firm is below the median value of all firms and equals zero otherwise. Table 6 reports the results. The positive coefficient on the triple interaction term means that innovation output of targeted classes increases more in firms with fewer technological classes. This result contradicts our reallocation hypothesis. Instead, it indicates that firms that concentrate innovation in fewer classes can conduct research in the targeted class where the patent value is more appropriable.

[Insert Table 6 about here]

\subsection{The aggregate effect of $M \& A s$}

As shown in the previous tables, M\&As between innovation-user and innovation-producer can enhance the innovation output of the targeted technological class as well as the combined firm. In this part, we consider the aggregate effect at technological class level. To be more specific, a technological class involved in related M\&As will experience an increase of innovation output. 
We then construct a class-year panel dataset. The dummy Targeted Class equals 1 if that class is involved in at least one innovation related mergers and 0 otherwise. We control for class fixed effects in the regressions. Results are reported in Table 7. The positive coefficient means that after mergers, the innovation output quantity increases in technological classes that are involved in innovation related mergers.

[Insert Table 7 about here]

\subsection{Withdrawn $M \& A s$}

We also employ the identification strategy developed by Savor and Lu (2009). They compare the change of innovation around successful mergers to that of mergers withdrawn for reasons that are exogenous to innovation. We followed Bena and $\mathrm{Li}$ (2014) to construct the control group using withdrawn M\&As. We begin with 191 unsuccessful friendly merger bids that are announced from 1984 to 2007 . We then keep deals where the news articles from Factiva did not mention R\&D activity as a reason for the failure. The categories of filters are presented in Table 8, Panel A. The final control group includes 67 unsuccessful merger bids.

Next, we construct the treatment sample of completed deals that: (i) involve acquirers and target firms of which data is available in Compustat/CRSP; (ii) occur in related (unrelated) acquirer-target industry pairs that match related (unrelated) industry pairs of the bids in the control sample and are announced within the three-year window centered at the announcement year of the bids in the control sample (514 deals). For the control sample that are matched to multiple deals, we select the closest completed deal in terms of the relative size ratio (target firm's total assets divided by acquirer's total assets).

To estimate the different effect from successful mergers and failed mergers, we create a dummy Treated that equals one for successful M\&As; Related equals one for M\&As of two firms 
from two related industries. Panel B shows that after a successful M\&As, the patents increase when the two firms are from related industries. Panel $\mathrm{C}$ reports the falsification test results in which we falsely assume that the onset of treatment occurs four years before it actually does. Results in Panel $\mathrm{C}$ are expected to be insignificant.

[Insert Table 8 about here]

\subsection{Robustness tests}

This study focuses on innovation user and innovation producer relationship instead of shared knowledge or technology proximity. Although our measure of innovation related M\&As is difference from M\&As between firms doing similar innovative research, it can still be the case that an industry is its own innovation user or producer, so that the increase of innovation is not from the synergy between innovation users and producers. To mitigate this concern, we exclude M\&As between firms from the same industry and estimate equation (1) again. The results in Table 9 shows that our results still hold.

[Insert Table 9 about here]

\section{Conclusions}

Fundamental innovations usually involve huge upfront costs, but the benefits are spread across various sectors and are difficult for the inventors to appropriate. That means the innovations possess positive externalities and are underinvested in by individual firms. We empirically show that after M\&As between firms from user industries and producer industries of innovations, the combined firm is able to internalize the positive externalities and enhance innovation output. We use failed M\&As as an identification strategy, and the results are robust. 
Using a firm tech-class level dataset, we find that the increase of firm level patents is driven by the patents in the technological class that is in a user-producer relationship with the target firm. While financially unconstrained acquirers fund more innovation in the targeted tech-classes, constrained firms move resources from other unaffected tech-classes to the targeted classes. The firm-class panel data also help to mitigate the concerns of mechanical increase and endogeneity. 


\section{Appendix: Variable Definitions}

NumPat: Natural logarithm of one plus firm i's total number of patents filed (and eventually granted) in year $t$.

NumCited: Natural logarithm of one plus a firm's total number of citations received on the firm's patents filed in year $t$. The total number of citations of a patent is the sum of citations within a three-year period starting from the patent award year.

CitePat: Natural logarithm of one plus the average number of citations received per patent of the firm's patents filed in year $t$.

CiteWeightPat: Natural logarithm of one plus the number of citation-weighted patents based on the total citations received by firm $i$ in year $t$. Citation-weighted patents are calculated as $\sum_{j} 1+C_{j} / \overline{C_{j}}$, where $C_{j}$ is the number of citations to patent $j$ and $\overline{C_{j}}$ is the mean number of citations to patents granted in the same year as patent $j$.

Generality: One minus the Herfindahl index of the citations received by the patent portfolio (patents filed by the firm in the previous five years) in year $t$ based on two-digit technology classes.

Originality: One minus the Herfindahl index of the citations made by the patent portfolio (patents filed by the firm in the previous five years) in year $t$ based on two-digit technology classes.

Patent Index: This measure is constructed in three steps. First, for each technology class $k$ and patent application year $t$, we compute the median value of the number of awarded patents in technology class $k$ with application year $t$ across all firms that were awarded at least one patent in technology class $k$ with application year $t$. Second, we scale the number of awarded patents to the acquirer/target firm in technology class $k$ with application year $t$ by the corresponding technology class-specific and application year-specific median value from the first step. Third, for the acquirer/target firm, we sum the scaled number of awarded patents from the second step across all technology classes and across application years. 


\section{References}

Aghion, P., N. Bloom, R. Blundell, R. Griffith, and P. Howitt. 2005. "Competition and innovation: An inverted-U relationship.” The Quarterly Journal of Economics 120, no. 2: 701-728.

Arrow, K. J. 1962. "The economic implications of learning by doing." The review of economic studies 29, no. 3: 155-173.

Bena, J., and K. Li. 2014. "Corporate Innovations and Mergers and Acquisitions.” Journal of Finance 69, no. 5: 1923-60.

Bloom, N., and J. Van Reenen. 2002. "Patents, Real Options and Firm Performance.” Economic Journal 112, no. 478: 97-116.

Brown, J. R., S. M. Fazzari, and B. C. Petersen. 2009. "Financing Innovation and Growth: Cash Flow, External Equity, and the 1990s R\&D Boom.” Journal of Finance 64, no. 1: 15185 .

Chang, X., K. Fu, A. Low, and W. Zhang. 2015. "Non-Executive Employee Stock Options and Corporate Innovation.” Journal of Financial Economics 115, no. 1: 168-88.

Chemmanur, T., E. Loutskina, and X. Tian. 2014. "Corporate Venture Capital, Value Creation, and Innovation.” Review of Financial Studies 27, no. 8: 2434-73.

Giroud, X., and H. M. Mueller. 2015. "Capital and labor reallocation within firms." The Journal of Finance 70, no. 4: 1767-1804.

Hall, B. H., A. Jaffe, and M. Trajtenberg. 2001. "The NBER Patent Citation Data File: Lessons, Insights and Methodological Tools.” NBER working paper no. 8498.

Hall, B. H., A. Jaffe, and M. Trajtenberg. 2005. "Market Value and Patent Citations." RAND Journal of Economics 36, no. 1: 16-38.

Hall, B. H., and J. Lerner. 2010. "The Financing of R\&D and Innovation." Chap. 14 in Handbook of the Economics of Innovation, vol. 1, edited by B. H. Hall and N. Rosenberg. Amsterdam, the Netherlands: North-Holland.

Kaplan, S. N., and L. Zingales. 1997. "Do investment-cash flow sensitivities provide useful measures of financing constraints?" The quarterly journal of economics 112, no. 1: 169215.

Kogan, L., D. Papanikolaou, A. Seru, and N. Stoffman. 2017. "Technological Innovation, Resource Allocation, and Growth." Quarterly Journal of Economics 132, no. 2: 665-712. 
Koh, P. S., and D. M. Reeb. 2015. "Missing R\&D.” Journal of Accounting and Economics 60, no. 1: 73-94.

Levine, R. 2005. "Finance and Growth: Theory and Evidence." Chap. 12 in Handbook of Economic Growth, vol. 1A, edited by P. Aghion and S. N. Durlauf. San Diego: Elsevier.

Mazzucato, M. 2015. The entrepreneurial state: Debunking public vs. private sector myths, vol. 1. Anthem Press, New York, N.Y.

Nelson, R. R. 1959. "The simple economics of basic scientific research." Journal of political economy 67, no. 3: 297-306.

Phillips, G. M., and A. Zhdanov. 2012. "R\&D and the Incentives from Merger and Acquisition Activity." Review of Financial Studies 26, no. 1: 34-78.

Savor, P. G., \& Q. Lu. 2009. "Do stock mergers create value for acquirers?” The Journal of Finance 64, no. 3: 1061-1097.

Seru, A. 2014. "Firm Boundaries Matter: Evidence from Conglomerates and R\&D Activity." Journal of Financial Economics 111, no. 2: 381-405.

Sevilir, M., and X. Tian. 2012. “Acquiring Innovation.” Working paper.

Stein, J. C. 1997. "Internal capital markets and the competition for corporate resources." The Journal of Finance 52, no. 1: 111-133. 


\section{Table 1: Summary statistics}

Panel A reports the summary statistics of key variables from 1984 to 2007, including 1,318 acquiring firms and 2,804 M\&A deals. If an acquiring firm conduct multiple M\&As within three years, we exclude all those deals. Based on our definition of industry-level innovation relationship, 1,567 $\mathrm{M} \& \mathrm{As}$ are between an innovation-user firm and an innovation-producer firm. The innovation measures are defined in the Appendix. Panel B, C, and D report the M\&A summary statistics. The sample includes acquiring firms that filed at least one patent one year prior to the mergers.

\section{Panel A: Firm summary}

\begin{tabular}{lrrr}
\hline & Mean & Median & St. dev. \\
\cline { 2 - 4 } Innovation Measures & & & \\
\#Patents & 30.400 & 3.688 & 107.171 \\
\#Citations & 54.932 & 4.000 & 221.505 \\
\#Citations per patent & 1.283 & 0.800 & 1.763 \\
\#Patent - Citationweighted & 61.403 & 6.157 & 220.182 \\
NumPat & 1.664 & 1.251 & 1.428 \\
NumCited & 1.495 & 1.011 & 1.498 \\
CitePat & 0.502 & 0.438 & 0.406 \\
CiteWeightPat & 1.975 & 1.576 & 1.628 \\
Patent Index & 17.746 & 2.328 & 59.269 \\
Originality & 0.479 & 0.500 & 0.287 \\
Generality & 0.459 & 0.481 & 0.287 \\
& & & \\
Control Variables & & & \\
Assets Total & & & \\
ROA & 4775.677 & 671.175 & 17351.520 \\
Leverage & 0.084 & 0.123 & 0.169 \\
R\&D/Assets & 0.210 & 0.195 & 0.156 \\
Capex/Assets & 0.092 & 0.059 & 0.106 \\
TobinQ & 0.057 & 0.050 & 0.034 \\
Tangibility & 2.376 & 1.834 & 1.604 \\
HHI & 0.253 & 0.205 & 0.178 \\
& 0.045 & 0.028 & 0.058 \\
\hline
\end{tabular}


Panel B: Distribution by year of execution

\begin{tabular}{lrrrrrrr}
\hline & $1984-$ & $1988-$ & $1992-$ & $1996-$ & $2000-$ & $2004-$ & \\
Period & 1987 & 1991 & 1995 & 1999 & 2003 & 2007 & Total \\
\hline \#M\&As & 296 & 307 & 371 & 690 & 725 & 415 & 2,804 \\
\#related M\&As & 110 & 135 & 192 & 413 & 455 & 262 & 1,567 \\
\hline
\end{tabular}

Panel C: Distribution of top five industries (4-digit SIC) for acquirers

\begin{tabular}{|c|c|c|c|c|c|}
\hline Industry (SIC) & $\begin{array}{r}\text { Prepackaged } \\
\text { Software } \\
(7372) \\
\end{array}$ & $\begin{array}{r}\text { miconductors } \\
\text { and Related } \\
\text { Devices } \\
(3674) \\
\end{array}$ & $\begin{array}{r}\text { Pharmaceutical } \\
\text { Preparations } \\
(2834) \\
\end{array}$ & $\begin{array}{r}\text { Biological } \\
\text { Products } \\
(2836) \\
\end{array}$ & $\begin{array}{r}\text { Surgical and } \\
\text { Medical } \\
\text { Instruments } \\
(3841) \\
\end{array}$ \\
\hline \#M\&As & 215 & 182 & 153 & 80 & 75 \\
\hline \#related M\&As & 184 & 155 & 139 & 69 & 56 \\
\hline
\end{tabular}

Panel D: Distribution of top five industries (4-digit SIC) for targets

\begin{tabular}{|c|c|c|c|c|c|}
\hline Industry (SIC) & $\begin{array}{r}\text { Prepackaged } \\
\text { Software } \\
(7372)\end{array}$ & $\begin{array}{r}\text { Semiconductors } \\
\text { and Related } \\
\text { Devices (3674) }\end{array}$ & $\begin{array}{r}\text { Pharmaceutical } \\
\text { Preparations } \\
(2834)\end{array}$ & $\begin{array}{r}\text { Surgical and } \\
\text { Medical } \\
\text { Instruments } \\
(3841)\end{array}$ & $\begin{array}{r}\text { Computer } \\
\text { Peripheral } \\
\text { Equipment } \\
(3577)\end{array}$ \\
\hline \#M\&As & 228 & 138 & 110 & 83 & 56 \\
\hline \#related M\&As & 179 & 128 & 106 & 68 & 52 \\
\hline
\end{tabular}

Panel E: Firm tech-class summary

\begin{tabular}{lcccccc}
\hline & \multicolumn{2}{c}{ All Classes } & \multicolumn{2}{c}{ Related Classes } & \multicolumn{2}{c}{ Other Classes } \\
\cline { 2 - 7 } & Mean & St. Dev. & Mean & St. Dev. & Mean & St. Dev. \\
\hline \#Patents & 6.643 & 20.445 & 10.279 & 29.128 & 5.530 & 16.768 \\
\#Citations & 15.525 & 72.853 & 25.094 & 107.390 & 12.597 & 58.035 \\
\#Patent - Citationweighted & 13.855 & 46.153 & 21.437 & 65.986 & 11.535 & 37.780 \\
NumPat & 0.449 & 0.820 & 0.812 & 1.090 & 0.383 & 0.742 \\
NumCited & 0.404 & 0.994 & 0.766 & 1.359 & 0.338 & 0.897 \\
CiteWeightPat & 0.577 & 1.039 & 1.026 & 1.348 & 0.496 & 0.951 \\
Patent Index & 1.262 & 5.847 & 2.685 & 9.063 & 1.004 & 5.008 \\
Originality & 0.143 & 0.272 & 0.251 & 0.321 & 0.123 & 0.258 \\
Generality & 0.137 & 0.267 & 0.237 & 0.317 & 0.119 & 0.253 \\
\hline
\end{tabular}




\section{Table 2: Univariate tests of innovation before and after M\&As}

This table provides univariate test results of the innovation and firm characteristics before and after M\&As. Panel A includes all related M\&As and Panel B includes all unrelated M\&As. An M\&A is defined as "related" if the target and the acquirer are from two related industries; two industries are defined as "related" if patents filed by firms in one industry is among the top three industries citing or been cited by patents filed by firms in another industry in the previous 10 years. Panel C reports the results from a difference-in-difference univariate test by comparing the change of variables around related M\&As to unrelated M\&As. The variables are the mean value of three years before or after M\&As.

Panel A: Related M\&As

\begin{tabular}{lccccc}
\hline & After & Before & Diff & $p$ value & $N$ \\
\hline \#Patents & 62.499 & 52.403 & 10.097 & 0.002 & 1,567 \\
\#Citations & 116.555 & 155.361 & -38.807 & 0.003 & 1,567 \\
\#Patent - Citationweighted & 130.816 & 116.135 & 14.681 & 0.041 & 1,567 \\
NumPat & 2.285 & 2.287 & -0.001 & 0.955 & 1,567 \\
NumCited & 1.822 & 2.522 & -0.701 & 0.000 & 1,567 \\
CiteWeightPat & 2.628 & 2.768 & -0.141 & 0.000 & 1,567 \\
Patent Index & 35.170 & 32.202 & 2.968 & 0.099 & 1,567 \\
Originality & 0.578 & 0.568 & 0.010 & 0.075 & 1,567 \\
Generality & 0.544 & 0.553 & -0.009 & 0.103 & 1,578 \\
R\&D/Assets & 0.099 & 0.106 & -0.008 & 0.000 & 1,408 \\
Assets Total & 7972.694 & 4376.186 & 3596.508 & 0.000 & 1,567 \\
ROA & 0.097 & 0.114 & -0.017 & 0.000 & 1,567 \\
Leverage & 0.209 & 0.169 & 0.040 & 0.000 & 1,567 \\
Capex/Assets & 0.046 & 0.064 & -0.017 & 0.000 & 1,567 \\
TobinQ & 2.236 & 3.110 & -0.874 & 0.000 & 1,567 \\
Tangibility & 0.211 & 0.240 & -0.030 & 0.000 & 1,567 \\
HHI & 0.036 & 0.030 & 0.005 & 0.000 & 1,567 \\
\hline
\end{tabular}


Panel B: Unrelated M\&As

\begin{tabular}{lccccc}
\hline & After & Before & Diff & $p$ value & $N$ \\
\hline \#Patents & 47.479 & 42.159 & 5.321 & 0.073 & 1,237 \\
\#Citations & 76.525 & 90.845 & -14.320 & 0.106 & 1,237 \\
\#Patent - Citationweighted & 95.285 & 82.948 & 12.337 & 0.040 & 1,237 \\
NumPat & 2.042 & 2.131 & -0.089 & 0.000 & 1,237 \\
NumCited & 1.652 & 2.090 & -0.438 & 0.000 & 1,237 \\
CiteWeightPat & 2.328 & 2.487 & -0.160 & 0.000 & 1,237 \\
Patent Index & 28.131 & 28.044 & 0.087 & 0.958 & 1,237 \\
Originality & 0.591 & 0.596 & -0.004 & 0.514 & 1,237 \\
Generality & 0.561 & 0.586 & -0.025 & 0.000 & 1,237 \\
R\&D/Assets & 0.046 & 0.051 & -0.005 & 0.000 & 951 \\
Assets Total & 11480.556 & 6995.843 & 4484.713 & 0.000 & 1,237 \\
ROA & 0.123 & 0.138 & -0.015 & 0.000 & 1,237 \\
Leverage & 0.263 & 0.228 & 0.035 & 0.000 & 1,237 \\
Capex/Assets & 0.051 & 0.065 & -0.014 & 0.000 & 1,237 \\
TobinQ & 1.740 & 1.985 & -0.245 & 0.000 & 1,237 \\
Tangibility & 0.278 & 0.310 & -0.032 & 0.000 & 1,237 \\
HHI & 0.062 & 0.058 & 0.004 & 0.000 & 1,237 \\
\hline
\end{tabular}

Panel C: Difference in difference

\begin{tabular}{lcccc}
\hline & Related & Unrelated & & \\
& Diff & Diff & DiD & $p$ value \\
\hline \#Patents & 10.097 & 5.321 & 4.776 & 0.143 \\
\#Citations & -38.807 & -14.320 & -24.487 & 0.071 \\
\#Patent - Citationweighted & 14.681 & 12.337 & 2.344 & 0.404 \\
NumPat & -0.001 & -0.089 & 0.088 & 0.008 \\
NumCited & -0.701 & -0.438 & -0.263 & 0.000 \\
CiteWeightPat & -0.141 & -0.160 & 0.019 & 0.329 \\
Patent Index & 2.968 & 0.087 & 2.881 & 0.123 \\
Originality & 0.010 & -0.004 & 0.014 & 0.048 \\
Generality & -0.009 & -0.025 & 0.016 & 0.032 \\
R\&D/Assets & -0.008 & -0.005 & -0.003 & 0.146 \\
Assets Total & 3596.508 & 4484.713 & -888.205 & 0.035 \\
ROA & -0.017 & -0.015 & -0.002 & 0.339 \\
Leverage & 0.040 & 0.035 & 0.005 & 0.175 \\
Capex/Assets & -0.017 & -0.014 & -0.003 & 0.000 \\
TobinQ & -0.874 & -0.245 & -0.629 & 0.000 \\
Tangibility & -0.030 & -0.032 & 0.002 & 0.167 \\
HHI & 0.005 & 0.004 & 0.001 & 0.247 \\
\hline
\end{tabular}


Table 3: Firm level innovation around related M\&As

This table tests the effects of related M\&As on firm innovation, using unrelated M\&As as a control group. The sample contains observations for six years before and six years after M\&A. The dependent variables are the six measures of firm innovations. The key independent variable, after, equals one if the observation is after the M\&As and zero otherwise. Related equals one if it is the merger is between firms from an innovation-user industry and an innovation-producer industry and equals zero otherwise. We include M\&A deal fixed effects and year fixed effects. The standard errors are clustered at the deal level.

\begin{tabular}{|c|c|c|c|c|c|c|}
\hline & $\begin{array}{c}\text { (1) } \\
\text { NumPat }\end{array}$ & $\begin{array}{c}\text { (2) } \\
\text { NumCited } \\
\end{array}$ & $\begin{array}{c}\text { (3) } \\
\text { CiteWeightPat } \\
\end{array}$ & $\begin{array}{c}(4) \\
\text { Ln(Patent } \\
\text { Index }) \\
\end{array}$ & $\begin{array}{c}\text { (5) } \\
\text { Originality } \\
\end{array}$ & $\begin{array}{c}(6) \\
\text { Generality } \\
\end{array}$ \\
\hline After & $\begin{array}{c}-0.196 * * * \\
(-7.641)\end{array}$ & $\begin{array}{c}-0.105^{* * *} \\
(-2.934)\end{array}$ & $\begin{array}{c}-0.198 * * * \\
(-6.588)\end{array}$ & $\begin{array}{c}-0.212 * * * \\
(-8.522)\end{array}$ & $\begin{array}{c}-0.0274 * * * \\
(-3.892)\end{array}$ & $\begin{array}{c}-0.0285 * * * \\
(-4.195)\end{array}$ \\
\hline After * Related & $\begin{array}{c}0.185^{* * * *} \\
(5.121)\end{array}$ & $\begin{array}{l}0.0583 \\
(1.160)\end{array}$ & $\begin{array}{c}0.138 * * * \\
(3.306)\end{array}$ & $\begin{array}{c}0.206^{* * * *} \\
(5.870)\end{array}$ & $\begin{array}{c}0.0189 * * \\
(2.131)\end{array}$ & $\begin{array}{c}0.0252 * * * \\
(2.942)\end{array}$ \\
\hline$R \& D / A s s e t s$ & $\begin{array}{c}0.309 * * \\
(2.392)\end{array}$ & $\begin{array}{c}0.517 * * * \\
(2.911)\end{array}$ & $\begin{array}{c}0.390 * * \\
(2.510)\end{array}$ & $\begin{array}{c}0.387 * * * \\
(3.030)\end{array}$ & $\begin{array}{l}0.0435 \\
(1.198)\end{array}$ & $\begin{array}{l}0.0104 \\
(0.323)\end{array}$ \\
\hline Sales & $\begin{array}{c}-0.162 * * * \\
(-3.891)\end{array}$ & $\begin{array}{c}-0.135^{* *} \\
(-2.320)\end{array}$ & $\begin{array}{c}-0.186 * * * \\
(-3.798)\end{array}$ & $\begin{array}{c}-0.153^{* * * *} \\
(-4.013)\end{array}$ & $\begin{array}{c}-0.0412 * * * \\
(-3.765)\end{array}$ & $\begin{array}{c}-0.0336 * * * \\
(-3.173)\end{array}$ \\
\hline$R O A$ & $\begin{array}{l}0.136^{*} \\
(1.669)\end{array}$ & $\begin{array}{l}0.188 * \\
(1.662)\end{array}$ & $\begin{array}{l}0.170 * \\
(1.793)\end{array}$ & $\begin{array}{c}0.172 * * \\
(2.185)\end{array}$ & $\begin{array}{l}0.0267 \\
(1.312)\end{array}$ & $\begin{array}{l}0.0214 \\
(1.102)\end{array}$ \\
\hline Leverage & $\begin{array}{c}-0.205 * * * \\
(-2.945)\end{array}$ & $\begin{array}{l}-0.178^{*} \\
(-1.828)\end{array}$ & $\begin{array}{c}-0.298 * * * \\
(-3.562)\end{array}$ & $\begin{array}{c}-0.200 * * * \\
(-2.986)\end{array}$ & $\begin{array}{c}0.00852 \\
(0.489)\end{array}$ & $\begin{array}{c}-0.0278 * \\
(-1.708)\end{array}$ \\
\hline Capex/Assets & $\begin{array}{c}-0.215 * * \\
(-1.967)\end{array}$ & $\begin{array}{c}-0.573 * * * \\
(-3.669)\end{array}$ & $\begin{array}{c}-0.339 * * * \\
(-2.580)\end{array}$ & $\begin{array}{c}-0.223 * * \\
(-2.168)\end{array}$ & $\begin{array}{c}0.0620^{*} \\
(1.943)\end{array}$ & $\begin{array}{c}0.0578^{*} \\
(1.857)\end{array}$ \\
\hline Tobin $Q$ & $\begin{array}{c}-0.00843^{* * *} \\
(-2.658)\end{array}$ & $\begin{array}{c}0.0232 * * * \\
(5.352)\end{array}$ & $\begin{array}{c}0.00552 \\
(1.488)\end{array}$ & $\begin{array}{c}-0.00505 \\
(-1.559)\end{array}$ & $\begin{array}{c}-0.00367 * * * \\
(-4.111)\end{array}$ & $\begin{array}{c}-0.00342 * * * \\
\quad(-4.026)\end{array}$ \\
\hline Tangibility & $\begin{array}{c}0.914 * * * \\
(4.608)\end{array}$ & $\begin{array}{c}1.496^{* * * *} \\
(5.184)\end{array}$ & $\begin{array}{c}1.155^{* * * *} \\
(4.854)\end{array}$ & $\begin{array}{c}0.776 * * * \\
(4.057)\end{array}$ & $\begin{array}{l}0.0549 \\
(0.916)\end{array}$ & $\begin{array}{l}0.00558 \\
(0.0950)\end{array}$ \\
\hline$H H I$ & $\begin{array}{c}0.241 * * \\
(2.334)\end{array}$ & $\begin{array}{c}-0.419 * * \\
(-2.540)\end{array}$ & $\begin{array}{c}0.186 \\
(1.367)\end{array}$ & $\begin{array}{c}0.257 * * * \\
(2.582)\end{array}$ & $\begin{array}{c}0.117 * * * \\
(3.471)\end{array}$ & $\begin{array}{c}0.108^{* * *} \\
(3.125)\end{array}$ \\
\hline Observations & 26,965 & 26,965 & 26,965 & 26,965 & 26,965 & 26,965 \\
\hline R-squared & 0.872 & 0.823 & 0.855 & 0.860 & 0.648 & 0.683 \\
\hline Deal FE & Yes & Yes & Yes & Yes & Yes & Yes \\
\hline Year FE & YES & YES & YES & YES & YES & YES \\
\hline Cluster & Deal & Deal & Deal & Deal & Deal & Deal \\
\hline
\end{tabular}


Table 4: Firm-class level innovation around M\&As

This table tests the effects of M\&As on firm-class level innovation output. The key independent variable, after, equals one if the observation is after the M\&As and zero otherwise. Targeted Class is a dummy variable that equals one if it is the technological class of the acquirer and the industry of the target has the innovation user-producer relationship and equals zero otherwise. We include M\&A deal fixed effects and class by year fixed effects. The standard errors are clustered at the deal level.

\begin{tabular}{|c|c|c|c|c|c|c|}
\hline & $\begin{array}{c}\text { (1) } \\
\text { NumPat }\end{array}$ & NumCited & $\begin{array}{c}\text { (3) } \\
\text { CiteWeightPat } \\
\end{array}$ & $\begin{array}{c}(4) \\
\text { Ln(Patent } \\
\text { Index }) \\
\end{array}$ & $\begin{array}{c}\text { (5) } \\
\text { Originality }\end{array}$ & $\begin{array}{c}\text { (6) } \\
\text { Generality }\end{array}$ \\
\hline After & $\begin{array}{c}-0.0163 * * * \\
(-3.055)\end{array}$ & $\begin{array}{c}0.00601 \\
(0.848)\end{array}$ & $\begin{array}{c}-0.0156^{* *} \\
(-2.338)\end{array}$ & $\begin{array}{c}-0.0131 * * * \\
(-2.925)\end{array}$ & $\begin{array}{c}-0.00398 * * \\
(-2.218)\end{array}$ & $\begin{array}{c}-0.00184 \\
(-1.067)\end{array}$ \\
\hline Targeted Class & $\begin{array}{c}0.265^{* * * *} \\
(14.28)\end{array}$ & $\begin{array}{c}0.296 * * * \\
(12.56)\end{array}$ & $\begin{array}{c}0.337 * * * \\
(14.92)\end{array}$ & $\begin{array}{c}0.213 * * * \\
(13.70)\end{array}$ & $\begin{array}{c}0.0679 * * * \\
(14.39)\end{array}$ & $\begin{array}{c}0.0685^{* * *} \\
(14.05)\end{array}$ \\
\hline After * Targeted Class & $\begin{array}{c}0.0473 * * * \\
(2.650)\end{array}$ & $\begin{array}{c}-0.0519 * * \\
(-2.110)\end{array}$ & $\begin{array}{l}0.0371^{*} \\
(1.752)\end{array}$ & $\begin{array}{c}0.0351 * * \\
(2.372)\end{array}$ & $\begin{array}{c}0.0212 * * * \\
(4.597)\end{array}$ & $\begin{array}{c}0.0190 * * * \\
(4.137)\end{array}$ \\
\hline$R \& D /$ Assets & $\begin{array}{c}0.127 * * \\
(2.295)\end{array}$ & $\begin{array}{l}0.162 * * \\
(2.263)\end{array}$ & $\begin{array}{l}0.161 * * \\
(2.414)\end{array}$ & $\begin{array}{c}0.121 * * \\
(2.554)\end{array}$ & $\begin{array}{l}0.0294 \\
(1.635)\end{array}$ & $\begin{array}{l}0.0226 \\
(1.322)\end{array}$ \\
\hline Sales & $\begin{array}{c}-0.0429 * * * \\
(-3.570)\end{array}$ & $\begin{array}{c}-0.0839 * * * \\
(-4.449)\end{array}$ & $\begin{array}{c}-0.0644 * * * \\
(-4.217)\end{array}$ & $\begin{array}{c}-0.0365 * * * \\
(-3.752)\end{array}$ & $\begin{array}{c}-0.0112 * * * \\
(-2.850)\end{array}$ & $\begin{array}{c}-0.0104 * * * \\
(-2.644)\end{array}$ \\
\hline$R O A$ & $\begin{array}{l}0.0548 \\
(1.543)\end{array}$ & $\begin{array}{c}0.150 * * * \\
(3.042)\end{array}$ & $\begin{array}{l}0.0585 \\
(1.366)\end{array}$ & $\begin{array}{c}0.0593 * * \\
(2.001)\end{array}$ & $\begin{array}{l}-0.0192 \\
(-1.627)\end{array}$ & $\begin{array}{l}-0.0119 \\
(-1.053)\end{array}$ \\
\hline Leverage & $\begin{array}{c}-0.0706 * * * \\
(-3.152)\end{array}$ & $\begin{array}{l}-0.0433 \\
(-1.467)\end{array}$ & $\begin{array}{c}-0.0860 * * * \\
(-3.155)\end{array}$ & $\begin{array}{c}-0.0623 * * * \\
(-3.340)\end{array}$ & $\begin{array}{l}-0.0114 \\
(-1.447)\end{array}$ & $\begin{array}{l}-0.0118 \\
(-1.450)\end{array}$ \\
\hline Capex/Assets & $\begin{array}{c}-0.173 * * \\
(-1.989)\end{array}$ & $\begin{array}{c}-0.134 \\
(-1.013)\end{array}$ & $\begin{array}{l}-0.158 \\
(-1.459)\end{array}$ & $\begin{array}{c}-0.114 \\
(-1.559)\end{array}$ & $\begin{array}{c}-0.124 * * * \\
(-4.242)\end{array}$ & $\begin{array}{c}-0.128 * * * \\
(-4.508)\end{array}$ \\
\hline TobinQ & $\begin{array}{c}-0.00415 * * * \\
(-2.767)\end{array}$ & $\begin{array}{c}0.00256 \\
(1.153)\end{array}$ & $\begin{array}{c}-0.00357^{*} \\
(-1.898)\end{array}$ & $\begin{array}{c}-0.00324 * * * \\
(-2.605)\end{array}$ & $\begin{array}{c}-0.00300^{* * *} * \\
(-5.783)\end{array}$ & $\begin{array}{c}-0.00282 * * * \\
(-5.876)\end{array}$ \\
\hline Tangibility & $\begin{array}{c}0.194 * * * \\
(3.595)\end{array}$ & $\begin{array}{c}0.309 * * * \\
(4.247)\end{array}$ & $\begin{array}{c}0.238 * * * \\
(3.657)\end{array}$ & $\begin{array}{c}0.158^{* * * *} \\
(3.505)\end{array}$ & $\begin{array}{c}0.101 * * * \\
(6.041)\end{array}$ & $\begin{array}{c}0.107 * * * \\
(6.255)\end{array}$ \\
\hline$H H I$ & $\begin{array}{c}0.104 * * \\
(2.415)\end{array}$ & $\begin{array}{l}-0.00460 \\
(-0.0735)\end{array}$ & $\begin{array}{l}0.120 * * \\
(2.138)\end{array}$ & $\begin{array}{c}0.0948 * * * \\
(2.729)\end{array}$ & $\begin{array}{c}0.0304 * * \\
(2.107)\end{array}$ & $\begin{array}{l}0.0179 \\
(1.429)\end{array}$ \\
\hline Observations & 319,884 & 319,884 & 319,884 & 319,884 & 319,884 & 319,884 \\
\hline R-squared & 0.533 & 0.502 & 0.509 & 0.509 & 0.403 & 0.416 \\
\hline Deal FE & Yes & Yes & Yes & Yes & Yes & Yes \\
\hline Class*Year FE & Yes & Yes & Yes & Yes & Yes & Yes \\
\hline Cluster & Deal & Deal & Deal & Deal & Deal & Deal \\
\hline
\end{tabular}




\section{Table 5: Firm heterogeneity - Financial constraints}

This table reports the effect of M\&As among financially constrained and non-constrained firms. Financially constrained (unconstrained) firms are firm whose measure of financial constraints lies above (below) the median across all firms one year before the mergers. Panel A include financially constrained firms. Panel A include financially unconstrained firms. We include M\&A deal fixed effects and class by year fixed effects. The standard errors are clustered at the deal level.

\section{Panel A: Subsample of financially constrained firms}

\begin{tabular}{|c|c|c|c|c|c|c|}
\hline VARIABLES & $\begin{array}{c}\text { (1) } \\
\text { NumPat }\end{array}$ & $\begin{array}{c}\text { (2) } \\
\text { NumCited } \\
\end{array}$ & $\begin{array}{c}\text { (3) } \\
\text { CiteWeightPat } \\
\end{array}$ & $\begin{array}{c}(4) \\
\text { Ln(Patent } \\
\text { Index }) \\
\end{array}$ & $\begin{array}{l}\text { (5) } \\
\text { Originality }\end{array}$ & $\begin{array}{c}\text { (6) } \\
\text { Generality } \\
\end{array}$ \\
\hline After & $\begin{array}{c}-0.0243 * * * \\
(-3.214)\end{array}$ & $\begin{array}{l}-0.0161 * \\
(-1.735)\end{array}$ & $\begin{array}{c}-0.0299 * * * \\
(-3.193)\end{array}$ & $\begin{array}{c}-0.0200 * * * \\
(-3.097)\end{array}$ & $\begin{array}{c}-0.00516^{*} \\
(-1.877)\end{array}$ & $\begin{array}{c}-0.00485^{*} \\
(-1.852)\end{array}$ \\
\hline Targeted Class & $\begin{array}{c}0.275^{* * * *} \\
(10.24)\end{array}$ & $\begin{array}{c}0.286^{* * * *} \\
(8.517)\end{array}$ & $\begin{array}{c}0.335^{* * * *} \\
(10.32)\end{array}$ & $\begin{array}{c}0.223 * * * \\
(9.822)\end{array}$ & $\begin{array}{c}0.0722 * * * \\
(10.09)\end{array}$ & $\begin{array}{c}0.0742 * * * \\
(9.753)\end{array}$ \\
\hline After $*$ Targeted Class & $\begin{array}{l}0.0300 \\
(1.101)\end{array}$ & $\begin{array}{c}-0.0793 * * \\
(-2.144)\end{array}$ & $\begin{array}{l}0.0315 \\
(0.987)\end{array}$ & $\begin{array}{l}0.0188 \\
(0.820)\end{array}$ & $\begin{array}{c}0.0189 * * * \\
(2.592)\end{array}$ & $\begin{array}{c}0.0224 * * * \\
(3.095)\end{array}$ \\
\hline$R \& D /$ Assets & $\begin{array}{l}0.200 * \\
(1.808)\end{array}$ & $\begin{array}{l}0.296^{*} \\
(1.873)\end{array}$ & $\begin{array}{l}0.259^{*} \\
(1.935)\end{array}$ & $\begin{array}{l}0.186^{* * *} \\
(1.983)\end{array}$ & $\begin{array}{l}0.0237 \\
(0.603)\end{array}$ & $\begin{array}{c}0.00716 \\
(0.196)\end{array}$ \\
\hline Sales & $\begin{array}{c}-0.0492 * * * \\
(-2.693)\end{array}$ & $\begin{array}{c}-0.0895 * * * \\
(-3.234)\end{array}$ & $\begin{array}{c}-0.0712 * * * \\
(-3.095)\end{array}$ & $\begin{array}{c}-0.0406^{* * *} \\
(-2.685)\end{array}$ & $\begin{array}{c}-0.0115^{*} \\
(-1.861)\end{array}$ & $\begin{array}{c}-0.0130 * * \\
(-2.069)\end{array}$ \\
\hline$R O A$ & $\begin{array}{l}0.0937 \\
(1.607)\end{array}$ & $\begin{array}{l}0.152 * \\
(1.825)\end{array}$ & $\begin{array}{c}0.110 \\
(1.569)\end{array}$ & $\begin{array}{l}0.0899^{*} \\
(1.798)\end{array}$ & $\begin{array}{l}-0.0240 \\
(-1.246)\end{array}$ & $\begin{array}{l}-0.0129 \\
(-0.699)\end{array}$ \\
\hline Leverage & $\begin{array}{l}-0.0550 * \\
(-1.725)\end{array}$ & $\begin{array}{c}-0.110^{* * *} \\
(-2.768)\end{array}$ & $\begin{array}{c}-0.0800 * * \\
(-2.051)\end{array}$ & $\begin{array}{l}-0.0515^{*} \\
(-1.921)\end{array}$ & $\begin{array}{c}-0.00978 \\
(-0.879)\end{array}$ & $\begin{array}{l}-0.00888 \\
(-0.785)\end{array}$ \\
\hline Capex/Assets & $\begin{array}{l}0.0669 \\
(0.578)\end{array}$ & $\begin{array}{c}0.203 \\
(1.170)\end{array}$ & $\begin{array}{l}0.0794 \\
(0.550)\end{array}$ & $\begin{array}{l}0.0904 \\
(0.960)\end{array}$ & $\begin{array}{l}-0.0529 \\
(-1.251)\end{array}$ & $\begin{array}{l}-0.0615 \\
(-1.541)\end{array}$ \\
\hline TobinQ & $\begin{array}{c}-0.00800 * * \\
(-2.491)\end{array}$ & $\begin{array}{c}-0.00217 \\
(-0.508)\end{array}$ & $\begin{array}{c}-0.00808 * * \\
(-2.125)\end{array}$ & $\begin{array}{c}-0.00642 * * \\
(-2.432)\end{array}$ & $\begin{array}{c}-0.00472 * * * \\
(-4.172)\end{array}$ & $\begin{array}{c}-0.00424 * * * \\
(-3.657)\end{array}$ \\
\hline Tangibility & $\begin{array}{l}0.134 * \\
(1.819)\end{array}$ & $\begin{array}{c}0.149 \\
(1.438)\end{array}$ & $\begin{array}{l}0.153^{*} \\
(1.714)\end{array}$ & $\begin{array}{l}0.109 * \\
(1.766)\end{array}$ & $\begin{array}{c}0.101 * * * \\
(4.186)\end{array}$ & $\begin{array}{c}0.112 * * * \\
(4.391)\end{array}$ \\
\hline$H H I$ & $\begin{array}{l}0.108 \\
(1.415)\end{array}$ & $\begin{array}{l}-0.00865 \\
(-0.0804)\end{array}$ & $\begin{array}{c}0.115 \\
(1.180)\end{array}$ & $\begin{array}{l}0.0865 \\
(1.395)\end{array}$ & $\begin{array}{l}0.0427^{*} \\
(1.780)\end{array}$ & $\begin{array}{l}0.0190 \\
(0.869)\end{array}$ \\
\hline Observations & 145,667 & 145,667 & 145,667 & 145,667 & 145,667 & 145,667 \\
\hline R-squared & 0.547 & 0.516 & 0.522 & 0.516 & 0.409 & 0.421 \\
\hline Deal FE & Yes & Yes & Yes & Yes & Yes & Yes \\
\hline Class*Year FE & Yes & Yes & Yes & Yes & Yes & Yes \\
\hline Cluster & Deal & Deal & Deal & Deal & Deal & Deal \\
\hline
\end{tabular}


Panel B: Subsample of financially unconstrained firms

\begin{tabular}{|c|c|c|c|c|c|c|}
\hline & $\begin{array}{c}\text { (1) } \\
\text { NumPat }\end{array}$ & $\begin{array}{c}\text { (2) } \\
\text { NumCited }\end{array}$ & CiteWeightPat & $\begin{array}{c}(4) \\
\text { Ln(Patent } \\
\text { Index })\end{array}$ & $\begin{array}{l}\text { (5) } \\
\text { Originality }\end{array}$ & $\begin{array}{c}\text { (6) } \\
\text { Generality }\end{array}$ \\
\hline After & $\begin{array}{c}-0.00173 \\
(-0.227)\end{array}$ & $\begin{array}{c}0.0233 * * \\
(2.178)\end{array}$ & $\begin{array}{c}0.00374 \\
(0.388)\end{array}$ & $\begin{array}{c}-0.000959 \\
(-0.153)\end{array}$ & $\begin{array}{c}-0.00233 \\
(-0.933)\end{array}$ & $\begin{array}{c}0.00145 \\
(0.603)\end{array}$ \\
\hline Targeted Class & $\begin{array}{c}0.253 * * * \\
(10.09)\end{array}$ & $\begin{array}{c}0.303 * * * \\
(9.390)\end{array}$ & $\begin{array}{c}0.335^{* * * *} \\
(10.90)\end{array}$ & $\begin{array}{c}0.203^{* * * *} \\
(9.674)\end{array}$ & $\begin{array}{c}0.0654 * * * \\
(10.40)\end{array}$ & $\begin{array}{c}0.0652 * * * \\
(10.28)\end{array}$ \\
\hline After * Targeted Class & $\begin{array}{c}0.0510 * * \\
(2.127)\end{array}$ & $\begin{array}{l}-0.0433 \\
(-1.301)\end{array}$ & $\begin{array}{l}0.0290 \\
(1.009)\end{array}$ & $\begin{array}{c}0.0405 * * \\
(2.063)\end{array}$ & $\begin{array}{c}0.0176^{* * * *} \\
(2.838)\end{array}$ & $\begin{array}{l}0.0111^{*} \\
(1.812)\end{array}$ \\
\hline$R \& D / A s s e t s$ & $\begin{array}{c}0.151 * * \\
(2.000)\end{array}$ & $\begin{array}{l}0.149^{*} \\
(1.708)\end{array}$ & $\begin{array}{l}0.168^{*} \\
(1.839)\end{array}$ & $\begin{array}{c}0.137^{* *} \\
(2.146)\end{array}$ & $\begin{array}{c}0.0454 * * \\
(2.020)\end{array}$ & $\begin{array}{c}0.0425^{* *} \\
(2.017)\end{array}$ \\
\hline Sales & $\begin{array}{l}-0.0266 \\
(-1.309)\end{array}$ & $\begin{array}{c}-0.0662 * * \\
(-2.139)\end{array}$ & $\begin{array}{l}-0.0412 \\
(-1.604)\end{array}$ & $\begin{array}{l}-0.0240 \\
(-1.472)\end{array}$ & $\begin{array}{l}-0.00695 \\
(-1.149)\end{array}$ & $\begin{array}{c}-0.00441 \\
(-0.740)\end{array}$ \\
\hline$R O A$ & $\begin{array}{l}0.0837 \\
(1.512)\end{array}$ & $\begin{array}{c}0.205 * * * \\
(2.831)\end{array}$ & $\begin{array}{l}0.0752 \\
(1.120)\end{array}$ & $\begin{array}{c}0.0854^{*} \\
(1.873)\end{array}$ & $\begin{array}{c}-0.00333 \\
(-0.185)\end{array}$ & $\begin{array}{c}-0.000958 \\
(-0.0557)\end{array}$ \\
\hline Leverage & $\begin{array}{c}-0.0892 * * * \\
(-2.601)\end{array}$ & $\begin{array}{l}0.0624 \\
(1.344)\end{array}$ & $\begin{array}{c}-0.0906 * * \\
(-2.172)\end{array}$ & $\begin{array}{c}-0.0761 * * * \\
(-2.693)\end{array}$ & $\begin{array}{l}-0.0126 \\
(-1.043)\end{array}$ & $\begin{array}{l}-0.0116 \\
(-0.917)\end{array}$ \\
\hline Capex/Assets & $\begin{array}{c}-0.262 * * \\
(-2.119)\end{array}$ & $\begin{array}{l}-0.316 \\
(-1.607)\end{array}$ & $\begin{array}{c}-0.227 \\
(-1.455)\end{array}$ & $\begin{array}{l}-0.181^{*} \\
(-1.729)\end{array}$ & $\begin{array}{c}-0.164 * * * \\
(-3.982)\end{array}$ & $\begin{array}{c}-0.157 * * * \\
(-3.792)\end{array}$ \\
\hline Tobin $Q$ & $\begin{array}{c}-0.00282 \\
(-1.521)\end{array}$ & $\begin{array}{c}0.00581^{* *} \\
(2.065)\end{array}$ & $\begin{array}{c}-0.00186 \\
(-0.772)\end{array}$ & $\begin{array}{l}-0.00219 \\
(-1.424)\end{array}$ & $\begin{array}{c}-0.00293 * * * \\
(-4.815)\end{array}$ & $\begin{array}{c}-0.00278 * * * \\
(-4.986)\end{array}$ \\
\hline Tangibility & $\begin{array}{c}0.242 * * * \\
(3.050)\end{array}$ & $\begin{array}{c}0.458 * * * \\
(4.411)\end{array}$ & $\begin{array}{c}0.300 * * * * \\
(3.128)\end{array}$ & $\begin{array}{c}0.199 * * * \\
(2.988)\end{array}$ & $\begin{array}{c}0.107 * * * \\
(4.355)\end{array}$ & $\begin{array}{c}0.104 * * * \\
(4.298)\end{array}$ \\
\hline$H H I$ & $\begin{array}{l}0.0761 \\
(1.414)\end{array}$ & $\begin{array}{l}0.0343 \\
(0.442)\end{array}$ & $\begin{array}{l}0.122 * \\
(1.715)\end{array}$ & $\begin{array}{l}0.0758^{*} \\
(1.768)\end{array}$ & $\begin{array}{l}0.0151 \\
(0.779)\end{array}$ & $\begin{array}{l}0.0119 \\
(0.720)\end{array}$ \\
\hline Observations & 166,805 & 166,805 & 166,805 & 166,805 & 166,805 & 166,805 \\
\hline R-squared & 0.565 & 0.532 & 0.544 & 0.550 & 0.443 & 0.458 \\
\hline Deal FE & Yes & Yes & Yes & Yes & Yes & Yes \\
\hline Class*Year FE & Yes & Yes & Yes & Yes & Yes & Yes \\
\hline Cluster & Deal & Deal & Deal & Deal & Deal & Deal \\
\hline
\end{tabular}


Table 6: Firm heterogeneity - Number of technological classes

This table reports the effect of M\&As among firms that conduct innovation in few technological classes and many technological classes. Few Classes is a dummy variable indicating whether the firm's number of technological classes is below the median across all firms one year before the mergers and equals zero otherwise. We include M\&A deal fixed effects, technological class and year fixed effects. The standard errors are clustered at the deal level.

\begin{tabular}{|c|c|c|c|c|c|c|}
\hline & $\begin{array}{c}\text { (1) } \\
\text { NumPat }\end{array}$ & $\begin{array}{c}\text { (2) } \\
\text { NumCited } \\
\end{array}$ & $\begin{array}{c}\text { (3) } \\
\text { CiteWeightPat } \\
\end{array}$ & $\begin{array}{c}(4) \\
\text { Ln(Patent } \\
\text { Index }) \\
\end{array}$ & $\begin{array}{c}\text { (5) } \\
\text { Originality } \\
\end{array}$ & $\begin{array}{c}\text { (6) } \\
\text { Generality } \\
\end{array}$ \\
\hline After & $\begin{array}{c}-0.0295 * * * \\
(-4.558)\end{array}$ & $\begin{array}{c}-0.0450 * * * \\
(-5.234)\end{array}$ & $\begin{array}{c}-0.0411 * * * \\
(-5.147)\end{array}$ & $\begin{array}{c}-0.0250 * * * \\
(-4.635)\end{array}$ & $\begin{array}{c}-0.00698 * * * \\
(-3.145)\end{array}$ & $\begin{array}{c}-0.00839 * * * \\
(-3.946)\end{array}$ \\
\hline Targeted Class & $\begin{array}{c}0.383 * * * \\
(16.42)\end{array}$ & $\begin{array}{c}0.459 * * * \\
(15.21)\end{array}$ & $\begin{array}{c}0.474 * * * \\
(16.72)\end{array}$ & $\begin{array}{c}0.306^{* * *} \\
(15.54)\end{array}$ & $\begin{array}{c}0.0879 * * * \\
(15.25)\end{array}$ & $\begin{array}{c}0.0898 * * * \\
(15.19)\end{array}$ \\
\hline After * Targeted Class & $\begin{array}{l}0.0261 \\
(1.138)\end{array}$ & $\begin{array}{c}-0.141 * * * \\
(-4.303)\end{array}$ & $\begin{array}{c}0.00747 \\
(0.276)\end{array}$ & $\begin{array}{l}0.0188 \\
(0.976)\end{array}$ & $\begin{array}{c}0.0123 * * \\
(2.240)\end{array}$ & $\begin{array}{c}0.0140 * * \\
(2.553)\end{array}$ \\
\hline After $*$ Few Classes & $\begin{array}{c}0.0438 * * * \\
(4.332)\end{array}$ & $\begin{array}{c}0.166 * * * \\
(10.94)\end{array}$ & $\begin{array}{c}0.0841 * * * \\
(6.529)\end{array}$ & $\begin{array}{c}0.0402 * * * \\
(4.869)\end{array}$ & $\begin{array}{c}0.00940^{* * * *} \\
(2.699)\end{array}$ & $\begin{array}{c}0.0216^{* * *} \\
(6.321)\end{array}$ \\
\hline Targeted Class * Few Classes & $\begin{array}{c}-0.399 * * * \\
(-14.75)\end{array}$ & $\begin{array}{c}-0.545 * * * \\
(-15.23)\end{array}$ & $\begin{array}{c}-0.459 * * * \\
(-13.71)\end{array}$ & $\begin{array}{c}-0.310 * * * \\
(-13.86)\end{array}$ & $\begin{array}{c}-0.0672 * * * \\
(-8.858)\end{array}$ & $\begin{array}{c}-0.0715 * * * \\
(-9.116)\end{array}$ \\
\hline After $*$ Targeted Class $*$ Few Classes & $\begin{array}{c}0.0731 * * * \\
(2.583)\end{array}$ & $\begin{array}{c}0.290 * * * \\
(7.365)\end{array}$ & $\begin{array}{c}0.100 * * * \\
(2.957)\end{array}$ & $\begin{array}{c}0.0553 * * \\
(2.398)\end{array}$ & $\begin{array}{c}0.0275^{* * * *} \\
(3.032)\end{array}$ & $\begin{array}{l}0.0139 \\
(1.600)\end{array}$ \\
\hline$R \& D /$ Assets & $\begin{array}{c}0.136^{* *} \\
(2.479)\end{array}$ & $\begin{array}{c}0.164 * * \\
(2.378)\end{array}$ & $\begin{array}{c}0.168 * * \\
(2.557)\end{array}$ & $\begin{array}{c}0.130 * * * \\
(2.781)\end{array}$ & $\begin{array}{c}0.0305^{*} \\
(1.707)\end{array}$ & $\begin{array}{l}0.0247 \\
(1.457)\end{array}$ \\
\hline Sales & $\begin{array}{c}-0.0406 * * * \\
(-3.421)\end{array}$ & $\begin{array}{c}-0.0794 * * * \\
(-4.230)\end{array}$ & $\begin{array}{c}-0.0608 * * * * \\
(-4.046)\end{array}$ & $\begin{array}{c}-0.0345^{* * *} * \\
(-3.593)\end{array}$ & $\begin{array}{c}-0.0109 * * * \\
(-2.756)\end{array}$ & $\begin{array}{c}-0.01000 * * \\
(-2.530)\end{array}$ \\
\hline$R O A$ & $\begin{array}{l}0.0541 \\
(1.528)\end{array}$ & $\begin{array}{c}0.126 * * * \\
(2.587)\end{array}$ & $\begin{array}{l}0.0527 \\
(1.237)\end{array}$ & $\begin{array}{c}0.0593 * * \\
(2.008)\end{array}$ & $\begin{array}{l}-0.0193 \\
(-1.633)\end{array}$ & $\begin{array}{l}-0.0135 \\
(-1.192)\end{array}$ \\
\hline Leverage & $\begin{array}{c}-0.0723 * * * \\
(-3.222)\end{array}$ & $\begin{array}{c}-0.0499 * \\
(-1.728)\end{array}$ & $\begin{array}{c}-0.0893 * * * \\
(-3.278)\end{array}$ & $\begin{array}{c}-0.0633 * * * \\
(-3.388)\end{array}$ & $\begin{array}{l}-0.0118 \\
(-1.497)\end{array}$ & $\begin{array}{l}-0.0126 \\
(-1.536)\end{array}$ \\
\hline Capex/Assets & $\begin{array}{l}-0.143^{*} \\
(-1.706)\end{array}$ & $\begin{array}{c}-0.114 \\
(-0.877)\end{array}$ & $\begin{array}{c}-0.128 \\
(-1.217)\end{array}$ & $\begin{array}{l}-0.0850 \\
(-1.222)\end{array}$ & $\begin{array}{c}-0.116^{* * *} \\
(-4.004)\end{array}$ & $\begin{array}{c}-0.124 * * * \\
(-4.389)\end{array}$ \\
\hline TobinQ & $\begin{array}{c}-0.00467 * * * * \\
(-2.939)\end{array}$ & $\begin{array}{c}0.00317 \\
(1.422)\end{array}$ & $\begin{array}{c}-0.00400 * * \\
(-1.997)\end{array}$ & $\begin{array}{c}-0.00368 * * * \\
(-2.800)\end{array}$ & $\begin{array}{c}-0.00332 * * * \\
(-6.270)\end{array}$ & $\begin{array}{c}-0.00307 * * * \\
(-6.122)\end{array}$ \\
\hline Tangibility & $\begin{array}{c}0.198 * * * \\
(3.716)\end{array}$ & $\begin{array}{c}0.290 * * * \\
(4.059)\end{array}$ & $\begin{array}{c}0.237 * * * \\
(3.674)\end{array}$ & $\begin{array}{c}0.162 * * * \\
(3.645)\end{array}$ & $\begin{array}{c}0.103 * * * \\
(6.102)\end{array}$ & $\begin{array}{c}0.107 * * * \\
(6.244)\end{array}$ \\
\hline$H H I$ & $\begin{array}{c}0.104 * * \\
(2.428)\end{array}$ & $\begin{array}{c}0.00704 \\
(0.114)\end{array}$ & $\begin{array}{c}0.124 * * \\
(2.205)\end{array}$ & $\begin{array}{c}0.0950^{* * * *} \\
(2.730)\end{array}$ & $\begin{array}{c}0.0305^{* *} \\
(2.103)\end{array}$ & $\begin{array}{l}0.0191 \\
(1.517)\end{array}$ \\
\hline Observations & 316,849 & 316,849 & 316,849 & 316,849 & 316,849 & 316,849 \\
\hline R-squared & 0.536 & 0.506 & 0.512 & 0.512 & 0.403 & 0.417 \\
\hline Deal FE & Yes & Yes & Yes & Yes & Yes & Yes \\
\hline Class*Year FE & Yes & Yes & Yes & Yes & Yes & Yes \\
\hline Cluster & Deal & Deal & Deal & Deal & Deal & Deal \\
\hline
\end{tabular}




\section{Table 7: Tech-class level regression}

This table tests the effect of related M\&As on technological level innovation output. The sample includes class-year observations. Targeted Class equals 1 if that class is involved in at least one innovation user-producer mergers and 0 otherwise.

\begin{tabular}{lccccc}
\hline & $(1)$ & $(2)$ & $(3)$ & $(4)$ & $(5)$ \\
& NumPat & NumCited & CiteWeightPat & Originality & Generality \\
\hline Targeted Class & & & & & \\
& $0.204 * * *$ & $0.0955^{* * *}$ & $0.217^{* * *}$ & $-0.00660^{* *}$ & 0.00295 \\
& $(4.726)$ & $(2.594)$ & $(4.829)$ & $(-2.126)$ & $(1.190)$ \\
Observations & & & & & \\
R-squared & 9,797 & 9,797 & 9,797 & 9,797 & 9,797 \\
Class FE & 0.886 & 0.847 & 0.877 & 0.717 & 0.727 \\
Year FE & Yes & Yes & Yes & Yes & Yes \\
Cluster & Yes & Yes & Yes & Yes & Yes \\
\hline & Class & Class & Class & Class & Class \\
\hline
\end{tabular}




\section{Table 8: Failed Mergers}

Panel A reports the steps to construct the control M\&A deals. We exclude deals that are withdrawn due to reasons endogenous to innovation. In Panel B, Treated is a dummy equals one if it is a successful M\&A and equals zero for a failed M\&A. Related equals one if it is the merger is between firms from an innovation-user industry and an innovation-producer industry and equals zero otherwise. In Panel C, we falsely assume that the onset of treatment occurs six years before it actually happens.

\section{Panel A: Control sample construction}

191 All unsuccessful merger bids (excluding financial firms)

-12 Difference in corporate philosophy over growth strategy (not involving R\&D)

-58 Other competing bids emerged and the acquisition with the competitor went through

-30 Valuation issues/Problem (not involving R\&D) revealed over the course of negotiations

-4 Market/analysts expected the deal to fail

-20 Not enough information/negotiations not completed/exogenous events (e.g., 1987 crash)

$67 \quad$ Final control group 
Panel B: Post-acquisition innovation

\begin{tabular}{|c|c|c|c|c|c|c|}
\hline & $\begin{array}{c}\text { (1) } \\
\text { NumPat }\end{array}$ & $\begin{array}{c}\text { (2) } \\
\text { NumCited }\end{array}$ & $\begin{array}{c}\text { (3) } \\
\text { CiteWeightPat }\end{array}$ & $\begin{array}{c}(4) \\
\text { Ln(Patent } \\
\text { Index }) \\
\end{array}$ & $\begin{array}{c}\text { (5) } \\
\text { Originality }\end{array}$ & $\begin{array}{c}(6) \\
\text { Generality }\end{array}$ \\
\hline After & $\begin{array}{c}1.286 * * * \\
(2.773)\end{array}$ & $\begin{array}{l}0.281^{*} \\
(1.992)\end{array}$ & $\begin{array}{c}1.489 * * * \\
(2.890)\end{array}$ & $\begin{array}{c}0.432 * * \\
(2.053)\end{array}$ & $\begin{array}{l}0.0743 \\
(1.162)\end{array}$ & $\begin{array}{l}0.0608 \\
(0.982)\end{array}$ \\
\hline Treated & $\begin{array}{c}0.829 \\
(0.973)\end{array}$ & $\begin{array}{c}0.139 \\
(0.626)\end{array}$ & $\begin{array}{c}0.837 \\
(0.900)\end{array}$ & $\begin{array}{c}0.289 \\
(0.777)\end{array}$ & $\begin{array}{c}0.112 \\
(1.133)\end{array}$ & $\begin{array}{l}0.0926 \\
(0.995)\end{array}$ \\
\hline After $*$ Treated & $\begin{array}{c}-1.305 * * * \\
(-4.038)\end{array}$ & $\begin{array}{l}-0.264^{*} \\
(-1.989)\end{array}$ & $\begin{array}{c}-1.499 * * * \\
(-4.229)\end{array}$ & $\begin{array}{c}-0.381 * * * \\
(-3.410)\end{array}$ & $\begin{array}{c}-0.168 * * * \\
(-2.712)\end{array}$ & $\begin{array}{c}-0.139 * * \\
(-2.661)\end{array}$ \\
\hline After * Related & $\begin{array}{c}-1.050 * * \\
(-2.523)\end{array}$ & $\begin{array}{c}-0.132 \\
(-0.713)\end{array}$ & $\begin{array}{c}-1.199 * * \\
(-2.513)\end{array}$ & $\begin{array}{c}-0.510 * * \\
(-2.483)\end{array}$ & $\begin{array}{l}0.0374 \\
(0.473)\end{array}$ & $\begin{array}{l}0.0719 \\
(0.969)\end{array}$ \\
\hline Treated $*$ Related & $\begin{array}{c}-0.253 \\
(-0.239)\end{array}$ & $\begin{array}{c}0.130 \\
(0.341)\end{array}$ & $\begin{array}{c}-0.0556 \\
(-0.0462)\end{array}$ & $\begin{array}{c}-0.171 \\
(-0.385)\end{array}$ & $\begin{array}{l}-0.0471 \\
(-0.317)\end{array}$ & $\begin{array}{l}0.0479 \\
(0.327)\end{array}$ \\
\hline After $*$ Treated $*$ Related & $\begin{array}{l}1.583 * * \\
(2.603)\end{array}$ & $\begin{array}{c}0.112 \\
(0.351)\end{array}$ & $\begin{array}{l}1.728 * * \\
(2.464)\end{array}$ & $\begin{array}{c}0.853 * * * \\
(3.086)\end{array}$ & $\begin{array}{l}0.0210 \\
(0.210)\end{array}$ & $\begin{array}{l}-0.0481 \\
(-0.514)\end{array}$ \\
\hline$R \& D /$ Assets & $\begin{array}{c}1.686 \\
(0.364)\end{array}$ & $\begin{array}{c}3.523 * * * \\
(2.759)\end{array}$ & $\begin{array}{c}3.578 \\
(0.762)\end{array}$ & $\begin{array}{c}-1.778 \\
(-1.268)\end{array}$ & $\begin{array}{c}1.874 * * * \\
(3.622)\end{array}$ & $\begin{array}{c}1.814 * * * \\
(3.928)\end{array}$ \\
\hline Sales & $\begin{array}{l}0.0478 \\
(0.484)\end{array}$ & $\begin{array}{l}-0.0604 \\
(-1.106)\end{array}$ & $\begin{array}{l}0.0258 \\
(0.230)\end{array}$ & $\begin{array}{l}0.0555 \\
(1.624)\end{array}$ & $\begin{array}{c}-0.0594 * * * \\
(-3.191)\end{array}$ & $\begin{array}{c}-0.0554 * * \\
(-2.339)\end{array}$ \\
\hline$R O A$ & $\begin{array}{c}3.312 * * \\
(2.112)\end{array}$ & $\begin{array}{c}0.426 \\
(0.606)\end{array}$ & $\begin{array}{l}3.067^{*} \\
(1.733)\end{array}$ & $\begin{array}{c}0.583 \\
(1.035)\end{array}$ & $\begin{array}{l}0.0832 \\
(0.343)\end{array}$ & $\begin{array}{c}0.114 \\
(0.472)\end{array}$ \\
\hline Leverage & $\begin{array}{c}0.389 \\
(0.385)\end{array}$ & $\begin{array}{l}-0.0416 \\
(-0.209)\end{array}$ & $\begin{array}{c}0.423 \\
(0.377)\end{array}$ & $\begin{array}{l}-0.0807 \\
(-0.200)\end{array}$ & $\begin{array}{c}0.190 \\
(1.657)\end{array}$ & $\begin{array}{c}0.266 * * * \\
(2.761)\end{array}$ \\
\hline Capex/Assets & $\begin{array}{c}1.952 \\
(1.538)\end{array}$ & $\begin{array}{c}0.856 \\
(1.227)\end{array}$ & $\begin{array}{c}2.423 \\
(1.542)\end{array}$ & $\begin{array}{c}0.440 \\
(1.150)\end{array}$ & $\begin{array}{c}0.278 \\
(1.424)\end{array}$ & $\begin{array}{c}0.316 \\
(1.625)\end{array}$ \\
\hline Tobin $Q$ & $\begin{array}{c}0.0998 * \\
(1.890)\end{array}$ & $\begin{array}{c}0.0889 * * * \\
(3.351)\end{array}$ & $\begin{array}{c}0.163 * * \\
(2.686)\end{array}$ & $\begin{array}{l}0.0314 \\
(1.310)\end{array}$ & $\begin{array}{c}0.0210 * * \\
(2.198)\end{array}$ & $\begin{array}{l}0.0152^{*} \\
(1.845)\end{array}$ \\
\hline Tangibility & $\begin{array}{c}-5.818 * * * \\
(-4.459)\end{array}$ & $\begin{array}{c}-1.465 * * \\
(-2.055)\end{array}$ & $\begin{array}{c}-6.592 * * * \\
(-4.087)\end{array}$ & $\begin{array}{c}-1.886 * * * \\
(-3.860)\end{array}$ & $\begin{array}{c}-0.398 * * \\
(-2.172)\end{array}$ & $\begin{array}{c}-0.471 * * \\
(-2.615)\end{array}$ \\
\hline$H H I$ & $\begin{array}{c}1.067 \\
(0.936)\end{array}$ & $\begin{array}{l}0.000613 \\
(0.00170)\end{array}$ & $\begin{array}{c}1.091 \\
(0.963)\end{array}$ & $\begin{array}{c}0.832 \\
(1.528)\end{array}$ & $\begin{array}{c}-0.101 \\
(-0.519)\end{array}$ & $\begin{array}{c}-0.165 \\
(-0.906)\end{array}$ \\
\hline Observations & 472 & 472 & 472 & 472 & 472 & 472 \\
\hline R-squared & 0.839 & 0.704 & 0.837 & 0.861 & 0.789 & 0.812 \\
\hline Deal FE & Yes & Yes & Yes & Yes & Yes & Yes \\
\hline Year FE & Yes & Yes & Yes & Yes & Yes & Yes \\
\hline Cluster & Deal & Deal & Deal & Deal & Deal & Deal \\
\hline
\end{tabular}




\begin{tabular}{|c|c|c|c|c|c|c|}
\hline & $\begin{array}{c}\text { (1) } \\
\text { NumPat }\end{array}$ & $\begin{array}{c}\text { (2) } \\
\text { NumCited }\end{array}$ & $\begin{array}{c}\text { (3) } \\
\text { CiteWeightPat }\end{array}$ & $\begin{array}{c}(4) \\
\text { Ln(Patent } \\
\text { Index }) \\
\end{array}$ & $\begin{array}{c}\text { (5) } \\
\text { Originality }\end{array}$ & $\begin{array}{c}(6) \\
\text { Generality }\end{array}$ \\
\hline After & $\begin{array}{c}0.502 \\
(0.425)\end{array}$ & $\begin{array}{l}-0.0919 \\
(-0.103)\end{array}$ & $\begin{array}{c}0.589 \\
(0.358)\end{array}$ & $\begin{array}{l}0.0295 \\
(0.130)\end{array}$ & $\begin{array}{c}0.112 \\
(0.488)\end{array}$ & $\begin{array}{c}-0.147 \\
(-0.468)\end{array}$ \\
\hline Treated & $\begin{array}{c}0.175 \\
(0.115)\end{array}$ & $\begin{array}{c}-0.186 \\
(-0.204)\end{array}$ & $\begin{array}{c}0.237 \\
(0.125)\end{array}$ & $\begin{array}{c}-0.463 \\
(-0.739)\end{array}$ & $\begin{array}{l}0.0269 \\
(0.107)\end{array}$ & $\begin{array}{c}-0.220 \\
(-0.696)\end{array}$ \\
\hline After $*$ Treated & $\begin{array}{c}-0.296 \\
(-0.230)\end{array}$ & $\begin{array}{c}0.540 \\
(0.598)\end{array}$ & $\begin{array}{c}-0.186 \\
(-0.107)\end{array}$ & $\begin{array}{c}0.245 \\
(0.575)\end{array}$ & $\begin{array}{l}0.0263 \\
(0.104)\end{array}$ & $\begin{array}{c}0.258 \\
(0.796)\end{array}$ \\
\hline After * Related & $\begin{array}{c}-0.599 \\
(-0.478)\end{array}$ & $\begin{array}{c}0.282 \\
(0.297)\end{array}$ & $\begin{array}{c}-0.522 \\
(-0.303)\end{array}$ & $\begin{array}{c}-0.146 \\
(-0.509)\end{array}$ & $\begin{array}{c}-0.125 \\
(-0.521)\end{array}$ & $\begin{array}{c}0.146 \\
(0.457)\end{array}$ \\
\hline Treated $*$ Related & $\begin{array}{c}-0.725 \\
(-0.460)\end{array}$ & $\begin{array}{c}0.977 \\
(0.891)\end{array}$ & $\begin{array}{c}-0.323 \\
(-0.156)\end{array}$ & $\begin{array}{c}-0.248 \\
(-0.351)\end{array}$ & $\begin{array}{l}-0.0873 \\
(-0.324)\end{array}$ & $\begin{array}{c}0.251 \\
(0.776)\end{array}$ \\
\hline After $*$ Treated $*$ Related & $\begin{array}{c}1.251 \\
(0.871)\end{array}$ & $\begin{array}{c}-0.710 \\
(-0.710)\end{array}$ & $\begin{array}{c}1.085 \\
(0.573)\end{array}$ & $\begin{array}{c}0.385 \\
(0.687)\end{array}$ & $\begin{array}{l}-0.0583 \\
(-0.222)\end{array}$ & $\begin{array}{c}-0.259 \\
(-0.779)\end{array}$ \\
\hline$R \& D /$ Assets & $\begin{array}{c}4.056 \\
(0.848)\end{array}$ & $\begin{array}{l}6.472 * \\
(1.939)\end{array}$ & $\begin{array}{c}7.001 \\
(1.273)\end{array}$ & $\begin{array}{c}2.373 \\
(1.137)\end{array}$ & $\begin{array}{l}1.828^{*} \\
(1.985)\end{array}$ & $\begin{array}{c}0.869 \\
(0.854)\end{array}$ \\
\hline Sales & $\begin{array}{c}-0.353 * * \\
(-2.600)\end{array}$ & $\begin{array}{c}-0.139 \\
(-1.301)\end{array}$ & $\begin{array}{c}-0.468 * * \\
(-2.482)\end{array}$ & $\begin{array}{l}-0.0602 \\
(-1.050)\end{array}$ & $\begin{array}{c}-0.140 * * * * \\
(-4.608)\end{array}$ & $\begin{array}{c}-0.134 * * * \\
(-4.114)\end{array}$ \\
\hline$R O A$ & $\begin{array}{c}5.032 * * \\
(2.593)\end{array}$ & $\begin{array}{c}2.518^{* *} \\
(2.569)\end{array}$ & $\begin{array}{c}6.211 * * * \\
(3.088)\end{array}$ & $\begin{array}{c}0.236 \\
(0.392)\end{array}$ & $\begin{array}{c}0.435 \\
(1.055)\end{array}$ & $\begin{array}{c}0.422 \\
(0.872)\end{array}$ \\
\hline Leverage & $\begin{array}{c}-0.868 \\
(-0.549)\end{array}$ & $\begin{array}{c}0.999 \\
(1.492)\end{array}$ & $\begin{array}{c}-0.187 \\
(-0.108)\end{array}$ & $\begin{array}{c}-0.725 \\
(-0.939)\end{array}$ & $\begin{array}{l}-0.437 * \\
(-1.881)\end{array}$ & $\begin{array}{l}-0.1000 \\
(-0.442)\end{array}$ \\
\hline Capex/Assets & $\begin{array}{c}0.888 \\
(0.678)\end{array}$ & $\begin{array}{c}0.131 \\
(0.162)\end{array}$ & $\begin{array}{c}0.924 \\
(0.624)\end{array}$ & $\begin{array}{c}-0.143 \\
(-0.301)\end{array}$ & $\begin{array}{c}0.268 \\
(1.110)\end{array}$ & $\begin{array}{c}0.138 \\
(0.548)\end{array}$ \\
\hline Tobin $Q$ & $\begin{array}{l}0.0505 \\
(0.613)\end{array}$ & $\begin{array}{c}0.130^{* *} \\
(2.385)\end{array}$ & $\begin{array}{c}0.144 \\
(1.491)\end{array}$ & $\begin{array}{l}0.0119 \\
(0.313)\end{array}$ & $\begin{array}{c}-0.0254 * \\
(-1.707)\end{array}$ & $\begin{array}{l}-0.0104 \\
(-0.690)\end{array}$ \\
\hline Tangibility & $\begin{array}{c}-6.025 * * * \\
(-2.797)\end{array}$ & $\begin{array}{c}-1.113 \\
(-0.854)\end{array}$ & $\begin{array}{c}-5.674 * * \\
(-2.299)\end{array}$ & $\begin{array}{c}-2.058 * * \\
(-2.389)\end{array}$ & $\begin{array}{c}-0.781 * * \\
(-2.317)\end{array}$ & $\begin{array}{c}-0.387 \\
(-0.982)\end{array}$ \\
\hline$H H I$ & $\begin{array}{c}9.605 \\
(1.122)\end{array}$ & $\begin{array}{l}-6.095^{*} \\
(-1.799)\end{array}$ & $\begin{array}{c}5.309 \\
(0.579)\end{array}$ & $\begin{array}{l}6.844 * * \\
(2.168)\end{array}$ & $\begin{array}{c}-1.079 \\
(-0.523)\end{array}$ & $\begin{array}{c}-1.939 \\
(-0.823)\end{array}$ \\
\hline Observations & 187 & 187 & 187 & 187 & 187 & 187 \\
\hline R-squared & 0.927 & 0.840 & 0.921 & 0.932 & 0.918 & 0.899 \\
\hline Deal FE & Yes & Yes & Yes & Yes & Yes & Yes \\
\hline Year FE & Yes & Yes & Yes & Yes & Yes & Yes \\
\hline Cluster & Deal & Deal & Deal & Deal & Deal & Deal \\
\hline
\end{tabular}


Table 9: Robustness check - Exclude M\&As from the same industry

This table tests the effects of related M\&As on firm innovation after excluding M\&As where acquirers and targets are from the same industry. The sample contains observations for six years before and six years after M\&As. The dependent variables are the six measures of firm innovations. The key independent variable, after, equals one if the observation is after the M\&As and zero otherwise. Related equals one if it is the merger is between firms from an innovation-user industry and an innovation-producer industry and equals zero otherwise. We include M\&A deal fixed effects and year fixed effects. The standard errors are clustered at the deal level.

\begin{tabular}{|c|c|c|c|c|c|c|}
\hline & $\begin{array}{c}\text { (1) } \\
\text { NumPat }\end{array}$ & $\begin{array}{c}\text { (2) } \\
\text { NumCited } \\
\end{array}$ & $\begin{array}{c}\text { (3) } \\
\text { CiteWeightPat } \\
\end{array}$ & $\begin{array}{c}(4) \\
\text { Ln(Patent } \\
\text { Index }) \\
\end{array}$ & $\begin{array}{c}\text { (5) } \\
\text { Originality } \\
\end{array}$ & $\begin{array}{c}\text { (6) } \\
\text { Generality } \\
\end{array}$ \\
\hline After & $\begin{array}{c}-0.103 * * * \\
(-4.174)\end{array}$ & $\begin{array}{l}-0.0530 \\
(-1.552)\end{array}$ & $\begin{array}{c}-0.118 * * * \\
(-4.109)\end{array}$ & $\begin{array}{c}-0.131 * * * \\
(-5.380)\end{array}$ & $\begin{array}{c}-0.0146 * * \\
(-2.063)\end{array}$ & $\begin{array}{c}-0.0210 * * * \\
(-3.110)\end{array}$ \\
\hline After $*$ Related & $\begin{array}{c}0.157 * * * \\
(3.109)\end{array}$ & $\begin{array}{l}0.0113 \\
(0.154)\end{array}$ & $\begin{array}{l}0.114 * \\
(1.951)\end{array}$ & $\begin{array}{c}0.193 * * * \\
(3.802)\end{array}$ & $\begin{array}{c}0.00378 \\
(0.334)\end{array}$ & $\begin{array}{c}0.0215^{*} \\
(1.953)\end{array}$ \\
\hline$R \& D /$ Assets & $\begin{array}{c}0.375^{* *} \\
(2.172)\end{array}$ & $\begin{array}{l}0.407 * \\
(1.694)\end{array}$ & $\begin{array}{c}0.402 * * \\
(1.979)\end{array}$ & $\begin{array}{c}0.448 * * \\
(2.424)\end{array}$ & $\begin{array}{l}0.0543 \\
(1.150)\end{array}$ & $\begin{array}{l}-0.00169 \\
(-0.0394)\end{array}$ \\
\hline Sales & $\begin{array}{c}-0.180 * * * \\
(-3.352)\end{array}$ & $\begin{array}{c}-0.104 \\
(-1.411)\end{array}$ & $\begin{array}{c}-0.183 * * * \\
(-2.926)\end{array}$ & $\begin{array}{c}-0.163 * * * \\
(-3.249)\end{array}$ & $\begin{array}{c}-0.0481 * * * \\
(-3.502)\end{array}$ & $\begin{array}{c}-0.0387 * * * \\
(-2.970)\end{array}$ \\
\hline$R O A$ & $\begin{array}{c}0.289 * * \\
(2.445)\end{array}$ & $\begin{array}{c}0.166 \\
(1.037)\end{array}$ & $\begin{array}{c}0.307 * * \\
(2.360)\end{array}$ & $\begin{array}{c}0.302 * * \\
(2.538)\end{array}$ & $\begin{array}{l}0.0343 \\
(1.302)\end{array}$ & $\begin{array}{l}0.0160 \\
(0.660)\end{array}$ \\
\hline Leverage & $\begin{array}{c}-0.124 \\
(-1.314)\end{array}$ & $\begin{array}{l}0.00266 \\
(0.0204)\end{array}$ & $\begin{array}{c}-0.155 \\
(-1.387)\end{array}$ & $\begin{array}{c}-0.146 \\
(-1.571)\end{array}$ & $\begin{array}{l}0.0164 \\
(0.743)\end{array}$ & $\begin{array}{c}-0.00563 \\
(-0.288)\end{array}$ \\
\hline Capex/Assets & $\begin{array}{c}-0.171 \\
(-1.277)\end{array}$ & $\begin{array}{c}-0.536 * * * \\
(-2.815)\end{array}$ & $\begin{array}{c}-0.341 * * \\
(-2.122)\end{array}$ & $\begin{array}{c}-0.184 \\
(-1.423)\end{array}$ & $\begin{array}{c}0.0827 * \\
(1.879)\end{array}$ & $\begin{array}{c}0.0724 * \\
(1.703)\end{array}$ \\
\hline TobinQ & $\begin{array}{c}-0.00814 \\
(-1.569)\end{array}$ & $\begin{array}{c}0.0267 * * * \\
(3.912)\end{array}$ & $\begin{array}{c}0.00658 \\
(1.112)\end{array}$ & $\begin{array}{c}-0.00362 \\
(-0.649)\end{array}$ & $\begin{array}{c}-0.00400 * * * \\
(-2.702)\end{array}$ & $\begin{array}{c}-0.00396 * * * \\
(-3.011)\end{array}$ \\
\hline Tangibility & $\begin{array}{c}0.787 * * * \\
(3.329)\end{array}$ & $\begin{array}{c}1.211 * * * \\
(3.444)\end{array}$ & $\begin{array}{c}1.128 * * * \\
(3.924)\end{array}$ & $\begin{array}{c}0.639 * * * \\
(2.696)\end{array}$ & $\begin{array}{l}0.00784 \\
(0.0958)\end{array}$ & $\begin{array}{l}-0.0272 \\
(-0.339)\end{array}$ \\
\hline HHI & $\begin{array}{c}0.146 \\
(1.010)\end{array}$ & $\begin{array}{c}-0.222 \\
(-0.968)\end{array}$ & $\begin{array}{c}0.230 \\
(1.194)\end{array}$ & $\begin{array}{c}0.127 \\
(0.900)\end{array}$ & $\begin{array}{c}0.100 * * \\
(1.975)\end{array}$ & $\begin{array}{c}0.0937 * \\
(1.806)\end{array}$ \\
\hline Observations & 15,579 & 15,579 & 15,579 & 15,579 & 15,579 & 15,579 \\
\hline R-squared & 0.880 & 0.834 & 0.865 & 0.864 & 0.646 & 0.686 \\
\hline Deal FE & Yes & Yes & Yes & Yes & Yes & Yes \\
\hline Year FE & Yes & Yes & Yes & Yes & Yes & Yes \\
\hline Cluster & Deal & Deal & Deal & Deal & Deal & Deal \\
\hline
\end{tabular}

